\title{
Critical Analysis of Non-Thermal Plasma-Driven Modulation of Immune Cells from Clinical Perspective
}

\author{
Barbora Smolková ${ }^{1}$, Adam Frtús ${ }^{1}$, Mariia Uzhytchak ${ }^{1}$, Mariia Lunova ${ }^{1,2} \oplus$, \\ Šárka Kubinová ${ }^{1,3}$, Alexandr Dejneka ${ }^{1}\left(\mathbb{D}\right.$ and Oleg Lunov ${ }^{1, *(1)}$ \\ 1 Department of Optical and Biophysical Systems, Institute of Physics of the Czech Academy of Sciences, \\ 18221 Prague, Czech Republic; smolkova@fzu.cz (B.S.); frtus@fzu.cz (A.F.); uzhytchak@fzu.cz (M.U.); \\ mariialunova@googlemail.com (M.L.); sarka.kubinova@iem.cas.cz (Š.K.); dejneka@fzu.cz (A.D.) \\ 2 Institute for Clinical \& Experimental Medicine (IKEM), 14021 Prague, Czech Republic \\ 3 Department of Biomaterials and Biophysical Methods, Institute of Experimental Medicine of the Czech \\ Academy of Sciences, 14220 Prague, Czech Republic \\ * Correspondence: lunov@fzu.cz; Tel.: +420-2660-52131
}

Received: 10 July 2020; Accepted: 26 August 2020; Published: 28 August 2020

\begin{abstract}
The emerged field of non-thermal plasma (NTP) shows great potential in the alteration of cell redox status, which can be utilized as a promising therapeutic implication. In recent years, the NTP field considerably progresses in the modulation of immune cell function leading to promising in vivo results. In fact, understanding the underlying cellular mechanisms triggered by NTP remains incomplete. In order to boost the field closer to real-life clinical applications, there is a need for a critical overview of the current state-of-the-art. In this review, we conduct a critical analysis of the NTP-triggered modulation of immune cells. Importantly, we analyze pitfalls in the field and identify persisting challenges. We show that the identification of misconceptions opens a door to the development of a research strategy to overcome these limitations. Finally, we propose the idea that solving problems highlighted in this review will accelerate the clinical translation of NTP-based treatments.
\end{abstract}

Keywords: non-thermal plasma; cytotoxicity; cell signaling; immunomodulation

\section{Introduction}

Implementation of technologies from physics in medical practice has a long history [1] and still shows significant renovation and progress [2]. As a result, there are expectations that physics-based techniques will bring novel diagnostics and treatment modalities in post-genomic personalized medicine [1]. In the last two decades, the research has shown that non-thermal plasma (also known as cold atmospheric plasma or non-equilibrium atmospheric pressure plasma) has significant potential in various biomedical applications [3-5]. Indeed, non-thermal plasma (NTP) has emerged as a promising tool for the sterilization of medical equipment [6-8], wound healing [9,10], bacteria eradication [11-14], dental hygiene [6,15], blood coagulation [16], angiogenesis suppression [17], cancer treatment [4,18,19], and food decontamination [20,21]. It is worth noting here that, while some studies show angiogenesis suppression [17], others describe accelerated angiogenesis by NTP [10,22].

Among those various biomedical applications of NTP, bacteria eradication and wound healing showed significant progress toward clinical application $[23,24]$. Indeed, several clinical trials revealed the potential applicability of NTP to decrease the bacterial load on chronic wounds in patients [25-28]. This success resulted in the commercialization of a number of plasma sources for wound healing and skin treatment $[29,30]$. Finally, in 2013, some NTP sources got CE certification as medical devices for 
the treatment of chronic wounds and pathogen-based skin diseases [23,24]. However, the research on NTP sources continues to develop extensive characterization and optimization of plasma systems and their biological effects $[30,31]$. Studies related to novel biomedical applications of NTP are currently actively expanding [30]. Thus, it is expected that, in the near future, the NTP field will bring other interesting possibilities for biology and medicine [30,32].

Basically, NTPs represent ionized gases with ion temperatures close to room temperature [33]. The composition of an NTP is very complex and consists of ions, charged molecules, electrons, electric fields, free radicals, low amounts of UV radiation, and neutral molecules [33]. Emerging evidence suggests that among other components, reactive oxygen species (ROS) and reactive nitrogen species (RNS) act as key mediators of biological responses triggered by NTP treatment [34-37]. In fact, ROS and RNS are well-known to regulate and influence key cellular processes, such as cell growth, migration, proliferation, differentiation, death, aging, inflammation and regeneration [38-44]. Different studies repeatedly showed that NTP is able to generate a number of ROS, such as $\mathrm{O},{ }^{\bullet} \mathrm{OH}, \mathrm{O}_{2}{ }^{\bullet-},{ }^{1} \mathrm{O}_{2}, \mathrm{NO}^{\bullet}$, $\mathrm{NO}_{2}{ }^{\bullet}, \mathrm{H}_{2} \mathrm{O}_{2}, \mathrm{NO}_{2}^{-}, \mathrm{NO}_{3}{ }^{-}$, or $\mathrm{O}_{3}$ [45]. Therefore, it is not surprising that NTP has such various biological effects. It is worth noting here that ROS and RNS intracellular actions also include promotion or suppression of inflammation, immunity, and carcinogenesis [44]. Thus, recent studies of the plasma field have focused on the potential immunomodulatory effects of NTP [46-48]. Research of such NTP applications is relatively new, but there are already substantial efforts and promising results toward immunomodulation by NTP. Therefore, this review aims to critically revisit the current literature about the NTP effects exerted on immune cells. One of the core principles of the scientific method is critical analysis. When we neglect critical assessment of the scientific literature, it leads to that questionable and irreproducible studies more likely stay unnoticed [49]. Irreproducible research not only wastes resources, hampers progress, and leads to frustration in academic science [50], but it also has devastating economical and personal consequences [51]. Thus, we herein describe and identify gaps in our understanding of underlying cellular mechanisms triggered by NTP. Identification of gaps in the scientific knowledge helps to shape the research process and provides a basement for the design of reliable and reproducible technologies. It is crucial to know the cellular mechanism of the treatment's action. Lack of such knowledge may result in severe clinical failure of desired treatment modality [52,53]. Indeed, identification of molecular targets of NTP action will enable better clinical transition of the technology. Finally, we discuss current challenges and perspectives in the biomedical applications of NTPs.

\section{A Brief Physicochemical Characterization of NTP for Biomedicine}

In this section, we would like to give only a brief overview with key points on the complicated question of the physicochemical characterization of NTP. There are many high-quality and comprehensive reviews on this issue $[24,30,33,45,54,55]$. Here, we give only a short description that is necessary to further understand the cellular effects of NTPs.

Current progress in the design and fabrication of various NTP systems allows us to relatively easy generate plasmas with temperature under $40{ }^{\circ} \mathrm{C}$ using different gases, e.g., helium, argon, nitrogen, ambient air, or a mixture of gases $[55,56]$. One can divide NTP systems into two generalized categories based on device principles, i.e., dielectric barrier discharge (DBD) and atmospheric pressure plasma jet (APPJ) [29,33]. DBD generates plasma in the gap between an isolated (dielectric) high-voltage electrode and a biological specimen (serving as a counter electrode) being exposed to NTP [33,57]. A non-thermal discharge is formed between these two electrodes when an alternating current (AC) high voltage of varying $\mathrm{kV}$ and up to $\mathrm{MHz}$ is applied $[33,45,57]$. In fact, the majority of DBD devices utilize atmospheric air as working gas $[33,45,57]$. One disadvantage of DBD systems is the high ignition voltage ( $10 \mathrm{kV}$ or more depending on the system's configuration). Thus, certain precautions or isolations are essential in DBD devices $[33,45,57]$. Due to the direct contact with tissue, DBD devices have shown a very promising effect in blood coagulation and tissue sterilization [16]. It is possible to replace one of the electrodes with an object with high charge storage capacity, creating a so-called 
"floating electrode" (FE) [58]. One can utilize living tissue for charge storage [58]. The system is called a "floating electrode DBD" (FE-DBD) [58]. The advantage of the FE-DBD system is in the absence of thermal or chemical damages during application on living tissues [58,59]. However, one should not forget that DBD systems operate with a relatively high current that has to pass through living tissue. Therefore, caution should be taken into account not to exceed safety limits [33,45,57].

Contrary to DBD, APPJ sources do not use the target area (namely biological object) as a counter electrode $[24,30,33,45,54,55]$. Instead, two electrodes within a device are utilized to create NTP, and then the NTP is transported to a desired biological object via diffusion or by a carrier gas. Different carrier gases can be used to create NTP. This allows the plasma-generated reactive species to be modified relatively easily. Thus, one can tune the chemical composition of the resulting NTP to reach the desired plasma compositions for specific biomedical applications [24,30,33,45,54,55]. Indeed, APPJ-based devices vary greatly in design and performance. One can produce systems that range from thin plasma needles, jets, and multiple jet applications up to large-size plasma torches [24,30,33,45,54,55].

The aforementioned complexity of NTP composition leads to the long list of up to 96 chemical reactions taking place in air NTP [60]. This illustrates how complex the entire NTP composition is (Figure 1). In fact, the quality and quantity of chemical entities that form NTP greatly vary depending on the type of gas being used to generate plasma [24,30,33,45,54,55,60-62]. Additionally, there is a number of ROS and RNS being produced as a result of plasma-liquid interactions (Table 1) [24,30,33,45,54,55,60-62]. The actual state of knowledge indicates that the biological effects of NTPs are mediated to a large extent by ROS, RNS generated in NTP and/or transferred into irradiated tissue $[24,30,33,45,54,55,60-62]$.

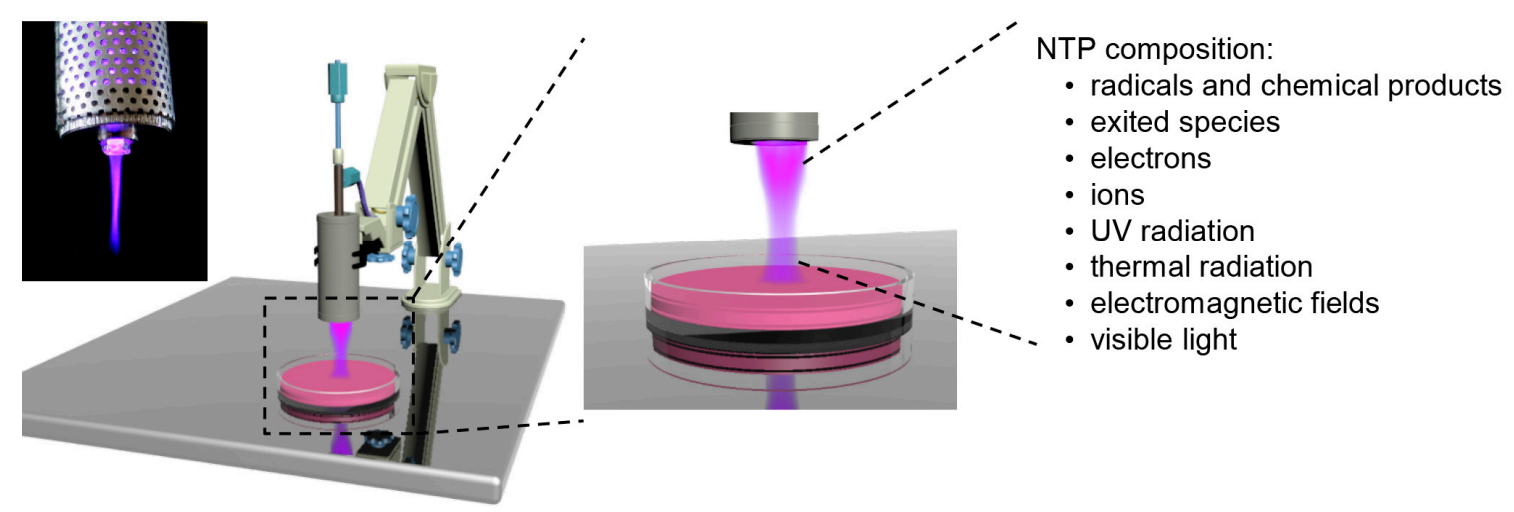

Figure 1. Schematics of atmospheric pressure plasma jet (APPJ) system with an image of the plasma torch. Image illustrates the entire physicochemical complexity of NTP.

Table 1. Major types of reactive oxygen and nitrogen species form by non-thermal plasma (NTP).

\begin{tabular}{cc}
\hline ROS or RNS Name & Chemical Formula \\
\hline Superoxide anion & $\mathrm{O}_{2}{ }^{-}$ \\
Hydrogen peroxide & $\mathrm{H}_{2} \mathrm{O}_{2}$ \\
Hydroxyl radical & $\bullet \mathrm{OH}$ \\
Singlet oxygen & ${ }^{1} \mathrm{O}_{2}$ \\
Ozone & $\mathrm{O}_{3}$ \\
Organic radicals & $\mathrm{RO}^{\bullet}, \mathrm{RO}_{2}$ \\
Nitric oxide & $\bullet \mathrm{NO}^{-}$ \\
Nitrogen dioxide & $\bullet \mathrm{NO}_{2}$ \\
Peroxynitrite & $\mathrm{ONOO}^{-}$ \\
\hline
\end{tabular}

One has to bear in mind that those ROS/RNS generated by NTP can be sub-divided in short-lived with a half-life in the $\mu$ s range $\left(\mathrm{O},{ }^{\bullet} \mathrm{OH}, \mathrm{O}_{2}{ }^{-},{ }^{1} \mathrm{O}_{2}, \mathrm{NO}^{\bullet}, \mathrm{NO}_{2}{ }^{\bullet}\right)$ and relatively long-lived with a half-life in the ms range $\left(\mathrm{H}_{2} \mathrm{O}_{2}, \mathrm{NO}_{2}{ }^{-}, \mathrm{NO}_{3}{ }^{-}, \mathrm{O}_{3}\right)[63,64]$. Additionally, one of the most abundant component of 
$\operatorname{NTP}\left(\mathrm{O}_{3}\right)$ has been shown to generate reactive oxygen intermediates (ROIs) with the chemical lifetime exceeding $100 \mathrm{~s}$ [65]. Thus, it is feasible that NTP would modulate redox reactions in living tissues. Of note, the penetration depth of plasma in tissues is relatively low $[36,63,66]$. It has been shown that NTP can reach a depth of $2 \mathrm{~mm}$ in vitro, contrary in in vivo conditions NTP penetrates only up to $\sim 400 \mu \mathrm{m}[36,63,66]$. It was proposed that the oxidizing nature of NTP may trigger alterations in redox-sensitive reactions and in a way affecting the microenvironment in deeper layers of the irradiated tissues $[34,36,67,68]$.

Indeed, ROS and RNS regulate the plethora of cellular processes [38-44]. As a result, NTP has been implicated to modify very distinct biological processes, ranging from increased proliferation $[69,70]$ to cell death by necrosis [71] or apoptosis [72-74]. Furthermore, the biological effects of NTPs greatly depend on the physical and chemical characteristics of plasma used for the treatment [62,75-77]. Another degree of variability in NTP devices is a very big range (from $0.5 \mathrm{kV}$ up to $100 \mathrm{kV}$ ) of the voltage producing discharges [33]. Furthermore, voltage frequencies that are used in different NTP sources vary enormously [33]. To sum up, different NTP sources vary in following major parameters of the system: feed gas compositions (e.g., $\mathrm{N}_{2}, \mathrm{O}_{2}$, artificial air $\left(80 \% \mathrm{~N}_{2}+20 \% \mathrm{O}_{2}\right)$, ambient air, Ar, He, mixture of gases), input power, discharge voltage, gas flow rate, jet length, voltage frequencies $[24,30,33,45,54,55]$. All these parameters affect the resulted physicochemical composition of NTP $[24,30,33,45,54,55]$.

\section{Critical Clinical View on NTP-Potential Side Effects and Clinical Validation}

Another very important topic that we want to touch before going to effects on immune cells is potential side effects. Indeed, we feel that this is a very important topic that is not comprehensively covered in plasma literature. There are only a few studies that mention the side effects of NTPs [78-80]. Generally, adverse drug reactions or side effects occur almost daily in healthcare institutions and have to be carefully considered in the optimization of treatment modalities [81-83]. It is plausible that such a complex composition of NTP may trigger different effects including side effects on human cells. For instance, it has been shown that ROS and RNS, as well as radiation energy of NTP, may trigger cellular toxicity and cause DNA damage [84,85]. Moreover, in redox biology, it is well-known, that intracellular accumulation of excessive levels of ROS damages cellular structures, leading to distinct types of cell death [86-89]. In fact, it has been shown that NTP may induce focal mucosal erosion with superficial ulceration and necrosis accompanied by a mild inflammatory reaction [79]. We summarized current studies that assessed side effects of NTP in Table 2. We performed this analysis to illustrate that the question about side effects elicited by NTP is still open. As one can see from Table 2, there is very limited number of studies that address side effects of NTP. In fact, the parameters of NTP treatment (duration, NTP voltage, frequency of treatment, etc.) in different studies varied, which precluded direct comparison and analysis. However, our intention was to highlight the necessity and importance of such studies. Generally, the assessment of side effects of a treatment is very important because side effects are crucial parameters in successful clinical performance [90]. Additionally, side effects threaten patient compliance [90]. 
Table 2. Studies that assessed side effects of NTP.

\begin{tabular}{ccccc}
\hline Plasma Type & Pathological Condition & Side Effects & Type of Study & Ref. \\
\hline APPJ & Chronic leg ulcers & No signs of cytotoxicity & Cohort study & {$[91]$} \\
DBD & Skin infection eczema & No side effects & Case study & {$[92]$} \\
APPJ & Chronic infected skin & Pain (before and after treatment) & Clinical trial & {$[25]$} \\
APPJ & wounds & No side effects & Case study & {$[23]$} \\
APPJ & Head and neck cancer & Bad taste, pain, collateral edema, & Case control study & {$[78]$} \\
APPJ & bleeding, sialorrhea, necrosis & Clinical trial & {$[93]$} \\
APPJ & Skin herpes zoster & No side effects & Case study & {$[94]$} \\
APPJ & Skin chronic wounds & No side effects & Case control study & {$[95]$} \\
& & No side effects & & {$[79]$} \\
APPJ & Skin wounds & supecal mucosal erosion with & Animal study & \\
\end{tabular}

One can see that available studies indicate that NTP treatment has no severe but only mild side effects and is well-tolerated (Table 2). Indeed, wounds and skin diseases represent the majority of pathological conditions where the side effects of NTP were assessed (Table 2). However, NTP treatment endeavors to attain different clinical applications (not only wound healing) $[4,18,19]$. Therefore, studies on potential side effects and those related to treatment complications should be scaled up.

As we will see further, NTP-induced immune cell modulation has significant potential to be a new treatment modality for cancer pathologies $[46,96]$. This is very appealing and encouraging. However, before we come close to NTP-induced immunomodulation, we need to at least very briefly discuss current views on clinical verification of treatment efficacy and good clinical practice. In fact, bias can explain extraordinary results that were not confirmed further in many individual studies [97]. The study design of meta-analysis and randomized clinical trials helps to avoid bias in questions of treatment effectiveness [97]. As a result, importance and influence of evidence-based research in medicine is constantly growing worldwide $[97,98]$. Indeed, evidence-based research becomes one of the most crucial medical milestones that affects the development of clinical guidelines [97-99]. It is worth noting here that clinical practice guidelines (CPGs) now represent concrete practice recommendations for healthcare providers [100-104]. CPGs represent a component of evidence-based medicine [100-104]. According to the principles of evidence-based medicine, CPGs are based on the extensive evaluations of whether evidence likely supports the efficacy of the treatment when taking into account risk-of-bias concepts [100-104]. This evaluation led to formulation of the so-called "evidence pyramid" (Figure 2) [105-108].

In fact, each ascending level of the pyramid (Figure 2) is represented by improved quality of evidence and decreased risk of bias [105-108]. Meta-analysis performs a crucial role in the formulation of CPGs [109-112]. Careful analysis of studies dealing with NTP side effects clearly shows that the majority of the reports are either case studies or case-control studies (Table 2). There are only a few randomized controlled trials with no meta-analysis performed (Table 2). It is important to realize the necessity of such analysis. Lack of systematic summaries leads to extreme inconsistency between evidence and expert recommendations [97-99]. If such recommendations rely on low-quality evidence from individual studies and/or preconceptions, this leads to destructive and disastrous consequences in clinical practice [97-99]. Thus, we have to be careful in our justifications of the efficacy of NTP treatment and the absence of side effects. 


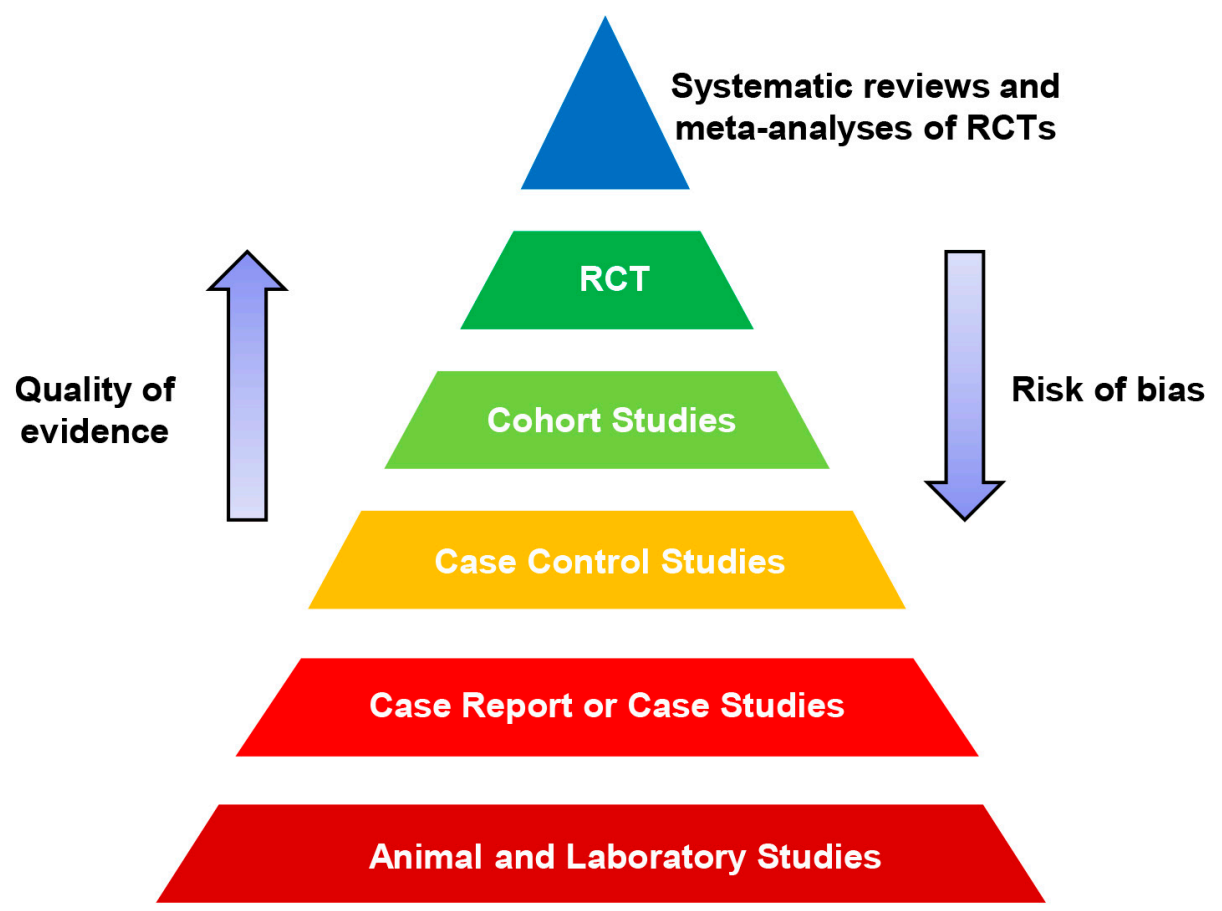

Figure 2. Hierarchy of evidence pyramid. RCT—randomized controlled trial.

\section{Effects of NTP on Immune Cells}

In the above section, we summarized that NTP has a very complicated physicochemical composition. However, ROS/RNS are now emphasized as major biological players of plasma. It is, indeed, plausible that ROS/RNS produced in plasmas are not necessarily the species directly affecting cells [113]. It is very likely that secondary products of oxidation and ROS/RNS formed and/or accumulated in cells play a greater role as biological effectors of NTP [36]. Taking into account that ROS and RNS participate, regulate, and modulate activity and responses of immune cells [44], NTP researchers have undertaken studies showing that NTP may also possess immunomodulation consequences [48].

It is worth noting here that a major function of the human immune system is to protect the body from infectious agents by different effector cells and proteins. In general, we recognize an innate immune system and an adaptive immune system. The innate immune system, consisting of phagocytic cells and natural barriers, is involved in unspecific host defense [114]. On the other hand, the adaptive immune system includes the antibody production and development of immunological memory in response to pathogens [115]. The progenitor hematopoietic stem cell may develop in myeloid (granulocytes, monocytes) or lymphoid (T, B, and natural killer cells) cells [115]. Monocytes, as effectors of the innate immune system, are responsible for engulfing pathogens and cellular debris in the human body [116]. In addition, monocytes are able to produce ROS and RNS, particularly nitric oxide radical $\left(\mathrm{NO}^{\bullet}\right)$ and hydrogen peroxide $\mathrm{H}_{2} \mathrm{O}_{2}$, to destroy phagocytized bacteria [117]. Upon infection, signal monocytes are recruited from the bloodstream to the place of inflammation and are differentiated into M1 or M2 macrophages. The process of macrophage polarization is driven by microenvironment at the site of inflammation [118].

It becomes evident that not only biochemical stimuli but also physical agents can stimulate the polarization of the macrophage and modulate the immune system [119,120]. Indeed, NTP treatment has shown the potential to enhance macrophage activation and polarization in vitro [121-123]. In fact, the literature on NTP effects on various immune cells is rapidly growing. Therefore, we propose here a critical overview of this topic. First of all, we summarized current state-of-the-art studies on NTP affecting immune cells in vitro in Table 3. 
Table 3. Generalized summary of NTP modulation of immune cell activity in vitro.

\begin{tabular}{|c|c|c|c|c|c|c|c|}
\hline \multirow{2}{*}{ Plasma Device } & \multicolumn{3}{|c|}{ Physicochemical Parameters } & \multirow{2}{*}{ Cell Lineage } & \multirow{2}{*}{ Signaling Pathway } & \multirow{2}{*}{ Main Results } & \multirow{2}{*}{ Ref. } \\
\hline & Gas & Voltage (kV) & Frequency & & & & \\
\hline kiNPen 11 & Ar & N.A. & $\sim 1 \mathrm{MHz}$ & THP-1 & Inflammation & $\begin{array}{l}\uparrow I L-8 \text { mRNA level and secretion; } \\
\uparrow H M O X \text { mRNA level }\end{array}$ & [124] \\
\hline kINPen 09 & Ar & $2-6$ & $\sim 1 \mathrm{MHz}$ & Jurkat and THP-1 & $\begin{array}{l}\text { Jurkat cells apoptosis, } \\
\text { THP-1 anti-oxidant } \\
\text { defense }\end{array}$ & $\begin{array}{l}\text { 个resistance of THP-1 to plasma-treated } \\
\text { medium in comparison to Jurkat cells; } \\
\text { differences in expression levels of genes } \\
\text { involved in redox and anti-oxidant system } \\
\text { regulation and apoptosis. }\end{array}$ & [125] \\
\hline APPJ & Air & 2 & N.A. & $\begin{array}{l}\text { THP-1, U937 and } \\
\text { RAW264.7, PBMCs }\end{array}$ & Apoptosis & $\begin{array}{c}\text { Inhibition of cell growth; } \\
\downarrow \text { Glucose consumption, } \\
\text { intracellular ATP and lactic acid production; } \\
\text { mitochondria membrane depolarization, } \\
\text { cytochrome c release and induction of } \\
\text { apoptosis. }\end{array}$ & [126] \\
\hline DBD & $\mathrm{N}_{4}$ & 1.08 & $30 \mathrm{kHz}$ & $\begin{array}{l}\text { T98G and A549 in } \\
\text { co-culture } \\
\text { with RAW264.7 }\end{array}$ & $\begin{array}{l}\text { Macrophage activation, } \\
\text { cancer cells death } \\
\text { induction }\end{array}$ & $\begin{array}{l}\text { } \text { expression of } i N O S \text { and TNF- } \alpha \text { genes on } \\
\text { mRNA and protein levels; } \\
\text { plasma-activated macrophages induced the } \\
\text { cell death of glioma and adenocarcinoma in } \\
\text { co-culture }\end{array}$ & [121] \\
\hline kINPen 11 & $\mathrm{Ar}$ & N.A. & $1 \mathrm{MHz}$ & $\begin{array}{l}\text { Neutrophils } \\
\text { isolated from } \\
\text { venous blood }\end{array}$ & NETosis & $\begin{array}{c}\text { Activation of NETosis in neutrophils; Release } \\
\text { of DNA, extracellular DNA. }\end{array}$ & [127] \\
\hline kINPen & Ar & N.A. & N.A. & $\begin{array}{l}\text { THP-1, A375, } \\
\text { primary } \\
\text { monocytes } \\
\text { isolated from } \\
\text { PBMCs }\end{array}$ & $\begin{array}{l}\text { Alternation in metabolic } \\
\text { activity } \\
\text { and morphology }\end{array}$ & $\begin{array}{c}\text { Altered the morphology of THP1 cells; } \\
\text { changes in surface markers expression; } \uparrow \text { IL8 } \\
\text { and MCP-1 in PMA-stimulated THP-1 } \uparrow \\
\text { IL1 } \beta, \text { IL6, and IL8 } \\
\uparrow H L A-D R \text { (an M1 macrophage marker) and } \\
\text { fibronectin (and M2 macrophage marker) }\end{array}$ & [122] \\
\hline
\end{tabular}


Table 3. Cont

\begin{tabular}{|c|c|c|c|c|c|c|c|}
\hline \multirow{2}{*}{ Plasma Device } & \multicolumn{3}{|c|}{ Physicochemical Parameters } & \multirow{2}{*}{ Cell Lineage } & \multirow{2}{*}{ Signaling Pathway } & \multirow{2}{*}{ Main Results } & \multirow{2}{*}{ Ref. } \\
\hline & Gas & Voltage (kV) & Frequency & & & & \\
\hline DBD & Air & 29 & 15 and $30 \mathrm{~Hz}$ & $\begin{array}{l}\text { THP-1, A549 in } \\
\text { co-culture }\end{array}$ & ICD & $\begin{array}{l}\text { induction of ICD in A549 cells } \\
\text { ( } \uparrow \text { calreticulin, ROS production, } \\
\text { ATP secretion); } \\
\downarrow \text { viability of Plasma treated A549 cells, } \\
\text { when co-cultured with M0 macrophages }\end{array}$ & [128] \\
\hline DBD & N.A. & 29 & $5,15,30,75 \mathrm{~Hz}$ & CNE-1, THP-1 & ER stress, ICD & $\begin{array}{l}\uparrow \text { immunogenic cell death of cancer cells; } \\
\uparrow \text { ATP secretion; } \\
\uparrow E R \text { stress proteins ( } \uparrow \text { ATF4-STC2 pathway). }\end{array}$ & [129] \\
\hline kiNPen & Ar & $2-6$ & $1.1 \mathrm{MHz}$ & Jurkat, THP-1 & Apoptosis & $\begin{array}{c}\uparrow \text { resistance of THP- } 1 \text { cells to plasma } \\
\text { treatment in comparison with Jurkat cells, } \\
\uparrow \text { caspase } 3 \text { dependent apoptosis; } \\
\uparrow \text { ERK } 1 / 2 \text { and MEK } 1 / 2 \text { and p38 MAPK and } \\
\text { JNK } 1 / 2 ; \\
\uparrow H S P 27 \text { in THP-1.t }\end{array}$ & [130] \\
\hline kiNPen & $\mathrm{Ar}$ & N.A. & $1 \mathrm{MHz}$ & Jurkat, U-937 & Apoptosis, Ferroptosis & $\begin{array}{l}\text { Plasma treatment in combination with } \\
\text { pulsed electric fields (electro square porator) } \\
\text { resulted in } \uparrow \text { cytotoxicity in Jurkat cells. } \\
\text { Contrary, the additive effect was smaller in } \\
\text { U937 cells; } \\
\text { activation of apoptosis; } \\
\uparrow \text { ROS production, caspase } 3 / 7 \text { activation). }\end{array}$ & [19] \\
\hline DBD & Air & 20 & $500 \mathrm{~Hz}$ & Jurkat & Apoptosis & $\begin{array}{c}\uparrow \mathrm{p} 53 \text { protein, but not on mRNA level } 48 \mathrm{~h} \\
\text { post plasma treatment; } \\
\uparrow \text { Bax and Bcl-2 proteins after } 24 \mathrm{~h}, \\
\text { slightly } \uparrow \text { caspase- } 8 ; \\
\uparrow \mathrm{mRNA} \text { levels of antioxidant enzyme SOD1, } \\
\text { CAT, and GSR2 } 6 \text { and } 24 \mathrm{~h} \text { post } \\
\text { NTP treatment } \\
\text { as a response to ROS elevated } \\
\text { oxidative stress }\end{array}$ & [131] \\
\hline
\end{tabular}


Table 3. Cont.

\begin{tabular}{|c|c|c|c|c|c|c|c|}
\hline \multirow{2}{*}{ Plasma Device } & \multicolumn{3}{|c|}{ Physicochemical Parameters } & \multirow{2}{*}{ Cell Lineage } & \multirow{2}{*}{ Signaling Pathway } & \multirow{2}{*}{ Main Results } & \multirow{2}{*}{ Ref. } \\
\hline & Gas & Voltage (kV) & Frequency & & & & \\
\hline kINPen & $\mathrm{Ar}$ & N.A. & N.A. & TK6 & DNA damage response & $\begin{array}{c}\uparrow \gamma \mathrm{H} 2 \mathrm{AX} \text { post plasma treatment as a } \\
\text { consequence of ROS induced } \\
\text { oxidative stress in apoptosis }\end{array}$ & [132] \\
\hline DBD & Air & 25 & $20 \mathrm{kHz}$ & $\begin{array}{l}\text { Human monocytes } \\
\text { isolated from } \\
\text { venous blood, } \\
\text { MDM }\end{array}$ & $\begin{array}{l}\text { ROS production, surface } \\
\text { markers expression }\end{array}$ & $\begin{array}{l}\downarrow \mathrm{CD} 86, \mathrm{CD} 36, \mathrm{CD} 163 \text { and CD206; } \\
\downarrow \mathrm{CD} 16 \text { post NTP treatment; } \\
\text { NTP treatment of MDM led to } \\
\text { time-dependent } \downarrow \mathrm{M} 1 \text { population, } \\
\text { significantly after } 30 \text { sec of treatment, } \\
\text { following } \uparrow \mathrm{M} 2 \text { population. }\end{array}$ & [133] \\
\hline kINPen MED & $\mathrm{Ar}$ & N.A. & N.A. & $\begin{array}{l}\text { MBMDc, PDA6606 } \\
\text { in co-culture }\end{array}$ & $\begin{array}{l}\text { Macrophage } \\
\text { polarization }\end{array}$ & $\begin{array}{c}\uparrow \text { NOS2 in TAM; } \\
\text { slight } \uparrow \text { M2 polarized macrophages post } \\
\text { exposure with plasma- treated medium; } \\
\uparrow C X C L 1 \text { and CCL4 in non-polarized } \\
\text { macrophages post plasma-treated medium; } \\
\downarrow \text { CXCL1, CCL4, MCP1 in TAM. }\end{array}$ & [123] \\
\hline kINPen & $\mathrm{Ar}$ & $2-6$ & $1 \mathrm{MHz}$ & $\begin{array}{l}\text { splenocytes of } \\
\text { mice spleens, } \\
\text { B16F10 in } \\
\text { co-culture }\end{array}$ & Immune cells activation & $\begin{array}{c}\downarrow \text { metabolic activity in naive and } \\
\text { PMA-stimulated splenocytes; } \\
\uparrow \text { IL-10, CCL4, IL-4, IL-12, and IL-1 } \beta \text { in } \\
\text { naive splenocytes; } \\
\text { calcium influx in splenocytic T-cells, but not } \\
\text { in macrophages; } \\
\text { Co-culturing of monocytes with } \\
\text { plasma-treated melanoma cells } \uparrow C D 115, \\
\text { IL-10 and CCL4, with a slightly } \uparrow I L-1 \beta \text {, } \\
\text { IL-12p70, TNF } \alpha \text {, and TGF } \beta \text {. } \\
\text { Co-culture of CD4+ T helper and CD8+ } \\
\text { cytotoxic T cells with plasma-treated } \\
\text { melanoma cells showed an increase of CD4 } \\
\text { over CD8 cells ( } \uparrow C D 28) \text {. }\end{array}$ & [134] \\
\hline $\begin{array}{l}\text { ATP-adenosir } \\
\text { HLA-ABC-hu } \\
\text { MBMDc-mur } \\
\text { traps; NETosis- } \\
\text { SOD1-superox } \\
\text { blood neutroph }\end{array}$ & $\begin{array}{l}\text { riphe } \\
\text { n le } \\
\text { bone- } \\
\text { utrop } \\
\text { dism } \\
\text { Z-VA }\end{array}$ & $\begin{array}{l}\text { e; ATF4-acti } \\
\text { e antigen AI } \\
\text { w derived cel } \\
\text { tracellular trap } \\
1 ; \text { STC2-stani } \\
\text { K-carbobenz }\end{array}$ & $\begin{array}{l}\text { transcript } \\
\text { MOX-hen } \\
\text { P1-mono } \\
\text { ation and } 1 \\
\text { in-2; TAM- } \\
\text { alyl-alanyl- }\end{array}$ & $\begin{array}{l}\text { tor 4; CAT-catalase } \\
\text { genase; HSP27-he } \\
\text { emoattractant protein } \\
\text { NOS2-nitric oxide s } \\
\text {-associated macropha } \\
\text { l-[O-methyl]- fluoro }\end{array}$ & $\begin{array}{l}\text { CL4-carbon tetrachloride } \\
\text { shock protein 27; ICD-i } \\
\text { IDM-monocyte-derived } \mathrm{m} \\
\text { hase; PBMCs-peripheral } \mathrm{l} \\
\text {; TGF } \beta \text {-transforming gron } \\
\text { hylketone; } \uparrow \text { - upregulation }\end{array}$ & $\begin{array}{l}\text { XCL1-C-X-C motif ligand 1; ER-endoplasmic } \\
\text { nunogenic cell death; iNOS-nitric oxide synt } \\
\text { ophages; N.A.-not assessed; NET-neutrophil ex } \\
\text { d mononuclear cells; PMA-phorbol-12-myristate } \\
\text { factor beta; TNF } \alpha \text {-tumor necrosis factor alpha; VB] } \\
\text { - downregulation. }\end{array}$ & $\begin{array}{l}\text { culum; } \\
\text { gene; } \\
\text { ellular } \\
\text { cetate; } \\
\text { enous }\end{array}$ \\
\hline
\end{tabular}


Indeed, there are more publications showing NTP effects on immune cells. However, we selected those that have shown a verifiable biological effect supported by rigorous methodology. We will come back to this point later, when discussing challenges with deciphering molecular mechanisms of NTP action. From Table 3, one can clearly see that NTP has potential in modulating immune cell activity with outcomes ranging from immune cells activation to induction of different kinds of cell death. A closer look at the results presented in Table 3 reveals that many studies used NTP treatment of immune cells not just for cellular function modulation solely but rather as a potential modality for cancer immunotherapy. In fact, recent advances in cancer immunotherapy showed that significant improvement in patient survival is possible with modern immunotherapy treatments $[135,136]$. Thus, the development of novel treatments (even maybe additive or complementary) in combination with existing immunotherapies is of a great importance. NTP may play here an emerging role to potentially improve clinical outcomes by supporting immunomodulatory effects.

THP-1 (acute monocytic leukemia cell line) showed greater resistance to plasma treatment in comparison to primary monocytes [137] and Jurkat (acute T cell leukemia cell line) cells [125,130]. NTP-treatment led to p53 [131] and caspase3/7 [130] activation and apoptosis execution in Jurkat cells. On the other hand, Kaushik et al. revealed that NTP led to the mitochondria membrane depolarization; cytochrome c release; and induction of apoptosis in THP-1, U937, and RAW264.7 cells [126]. Furthermore, NTP-treatment triggered neutrophil extracellular traps (NET) formation and the IL-8 release, perhaps as an outcome of cell death [127].

Further analysis of the Table 3 brings us to the conclusion that the majority of the research is done utilizing monocytic cell lineages. Furthermore, studies summarized in Table 3 show that NTP modulates immune cells via redox signaling consistent with the current hypothesis of NTP cellular action. Indeed, NTP-derived ROS and RNS can induce the immunological response in many cell types (for more information, see Table 3). In general, ROS and RNS are involved in many cellular processes, and at lower concentrations, they positively regulate the immune system [138]. Thus, the manipulation of ROS balance may be an interesting therapeutic approach in many diseases, including cancer [139]. Recently, a number of studies reported the activation of immunogenic cell death in cancer cells post NTP-treatment in vitro $[128,129,140,141]$. However, assessment solely enhanced levels of damage-associated molecular patterns (DAMPs, such as ATP increase, CRT activation) as a final proof of ICD in vitro is not sufficient. Thus, the potential of an agent to activate bona fide ICD has to be evaluated in vivo [142,143]. In fact, only a limited number of reports shows the ICD stimulation post direct or indirect (NTP-treated liquids) NTP treatment in vivo in appropriate animal models of oncogenesis [46,96].

However, in order to come closer to the real-life clinical approach, thorough in vivo validation should be performed. NTP shows some promising results in vivo as well. We summarized current in vivo studies on NTP-induced modulation of immune cell activity in Table 4. We have to say, that there are more in vivo studies dealing with NTP modulation of immune cell activity. However, the vast majority of those reports is rather descriptive in nature. Thus, it is not surprising that the molecular foundations for the alleged immunomodulatory effects remain generally enigmatic. In the absence of a hypothetical mechanism to guide experimental design, proper adjustment and control of the experimental parameters are usually precluded. Therefore, we selected in Table 4 studies that comply with following criteria: availability of statistical assessment, presence of positive controls for immunomodulatory assays, orthogonal validation of immunomodulation, and several replicates of proof of the concept experiments. 
Table 4. Summary of NTP modulation of immune cell activity in vivo.

\begin{tabular}{|c|c|c|c|c|c|c|c|}
\hline \multirow{2}{*}{ Plasma Device } & \multicolumn{3}{|c|}{ Physicochemical Parameters } & \multirow{2}{*}{ Animal Model } & \multirow{2}{*}{ Signaling Pathway } & \multirow{2}{*}{ Main Results } & \multirow{2}{*}{ Ref } \\
\hline & Gas & Voltage (kV) & Frequency & & & & \\
\hline kINPen MED & $\mathrm{Ar}$ & N.A. & N.A. & C57BL/6 mice & Immuno-modulation & $\begin{array}{c}\downarrow \text { total number of tumor nodes; } \\
\text { 个infiltration of macrophages, but not CD206+ } \\
\text { cells into tumors; } \\
\uparrow \text { number of macrophages and T cells, } \\
\text { with no changes in numbers of dendritic cells } \\
\text { and neutrophils. Increased level of calreticulin }\end{array}$ & [144] \\
\hline kINPen MED & $\mathrm{Ar}$ & N.A. & $1 \mathrm{MHz}$ & C57BL/6 mice & $\begin{array}{l}\text { Apoptosis in tumor } \\
\text { tissue }\end{array}$ & $\begin{array}{l}\text { Induction of apoptosis in tumor tissues; } \\
\text { No significant differences in the number of } \\
\text { granulocytes, monocytes, and lymphocytes } \\
\text { in general; } \\
\text { No changes in cytokines secretion of IL6, IL10, } \\
\text { IL12, MCP1, IFN } \gamma \text {, or TNF } \alpha \text {. }\end{array}$ & [145] \\
\hline APPJ & $\mathrm{O}_{2}$ or $\mathrm{N}_{2}$ & 24 & N.A. & $\begin{array}{l}\text { CD2F1 and } \\
\text { C57BL/6 mice }\end{array}$ & $\begin{array}{l}\text { Tumor growth } \\
\text { inhibition }\end{array}$ & $\begin{array}{c}\text { \tumor size in CD2F1 mice; } \\
\uparrow \text { IFN- } \gamma \text {, no changes in TNF- } \alpha \text { from } \\
\text { splenocytes of the plasma-treated CD2F1 mice; } \\
\text { In the C57BL/6 mice very weak response to } \\
\text { plasma-treatment; } \\
\text { Discussion on immune response, but no data } \\
\text { are provide to } \\
\text { support it. }\end{array}$ & [146] \\
\hline kINPen & Ar & N.A. & N.A. & Balb/C mice & ICD & $\begin{array}{c}\text { } \text { immunogenic cell death markers in } \\
\text { CT-26 cells; } \\
\text { heat shock protein } 70 \text { (HSP70), and } \\
\text { high-mobility-group-protein B1 (HMGB1); } \\
\uparrow I L 1 \beta, \text { IL6, IL12p70, CCL4, and TNF } \alpha . \\
\uparrow \text { number of macrophages and T cells in mice } \\
\text { with CT26 peritoneal carcinomatosis post } \\
\text { treatment with oxidized saline solution. }\end{array}$ & [96] \\
\hline
\end{tabular}


Table 4. Cont

\begin{tabular}{|c|c|c|c|c|c|c|c|}
\hline \multirow{2}{*}{ Plasma Device } & \multicolumn{3}{|c|}{ Physicochemical Parameters } & \multirow{2}{*}{ Animal Model } & \multirow{2}{*}{ Signaling Pathway } & \multirow{2}{*}{ Main Results } & \multirow{2}{*}{ Ref. } \\
\hline & Gas & Voltage (kV) & Frequency & & & & \\
\hline DBD & Air & 17 & $50-500 \mathrm{~Hz}$ & C57BL/6J mice & ICD & $\begin{array}{l}\text { Activation of immunogenic cell death marker } \\
\text { (calreticulin); } \\
\uparrow \text { survival rate of mice post vaccine injection } \\
\text { prepared from B16F10 melanoma cells treated } \\
\text { with DBD plasma. }\end{array}$ & [48] \\
\hline kINPen & $\begin{array}{c}\mathrm{Ar}, \\
\mathrm{Ar}+\mathrm{O}_{2} \\
\mathrm{He}, \\
\mathrm{He}+\mathrm{O}_{2}\end{array}$ & N.A. & $1 \mathrm{MHz}$ & C57BL/6 mice & ICD & $\begin{array}{c}\downarrow \text { tumor growth } \\
\uparrow \text { CD8+ cytotoxic T-cells; } \\
\uparrow \text { macrophages; } \\
\uparrow \text { CD11c+ dendritic cells (DCs); } \\
\uparrow C D 127 \text { in both CD4+ and CD8+ T-cells; } \\
\uparrow \text { ICD markers in B16F10 ( } \uparrow \text { CRT, HSP90, CD47); } \\
\text { Co-culture of splenocytes isolated from } \\
\text { vaccinated mice with B16F10 } \uparrow \text { marker CD69 in } \\
\text { CD8+ T cells and } \uparrow C X C L 1, \text { CXCL10, IFN } \gamma, \\
\text { IL1 } \alpha, \text { IL6, and TNF } \alpha ; \\
\downarrow G M-C S F, \text { CCL17. }\end{array}$ & [46] \\
\hline APPJ & $\mathrm{N}_{2}$ & N.A. & N.A. & C57/BL6 mice & $\begin{array}{c}\text { Anti-inflammatory } \\
\text { effect }\end{array}$ & $\begin{array}{c}\downarrow \text { immune cells infiltration (CD4+ T cells, } \\
\text { CD11c+ cells, CD11b+ cells, and Gr-1+ cells); } \\
\downarrow \text { pro-inflammatory cytokine and chemokine } \\
\text { (IL-6, IL-17, IL-22, CCL20 and CXCL1); } \\
\downarrow \text { Th17 cell differentiation in lymph node; } \\
\text { In vitro suppressed differentiation of naive } \\
\text { CD4+T cells into Th17 cells and Th1 cells; } \\
\downarrow \text { CD80, CD86, and MHCII in BDCM and } \downarrow I L-6 \\
\text { expression TNF- } \alpha \text { and IL-6. }\end{array}$ & [147] \\
\hline
\end{tabular}


Table 4. Cont.

\begin{tabular}{|c|c|c|c|c|c|c|c|}
\hline \multirow{2}{*}{ Plasma Device } & \multicolumn{3}{|c|}{ Physicochemical Parameters } & \multirow{2}{*}{ Animal Model } & \multirow{2}{*}{ Signaling Pathway } & \multirow{2}{*}{ Main Results } & \multirow{2}{*}{ Ref } \\
\hline & Gas & Voltage (kV) & Frequency & & & & \\
\hline APPJ & $\mathrm{N}_{2}$ & 5 & $15 \mathrm{kHz}$ & NC/Nga mice & $\begin{array}{c}\text { Anti-inflammatory } \\
\text { effect }\end{array}$ & $\begin{array}{c}\text { In vivo: NTP treatment } \downarrow \text { HDM-induced } \\
\text { infiltration of mast cells and eosinophil into } \\
\text { the dermis and } \downarrow \text { Th2 cell differentiation; } \\
\downarrow \text { TSLP and CCL17 post NTP treatment in } \\
\text { HDM-induced AD; } \\
\text { In vitro: Activated mast cells incubation in } \\
\text { plasma- treated medium resulted in } \downarrow N F-\kappa B \text {, } \\
T N F-\alpha, I L-6 \text { and } I L-13\end{array}$ & [148] \\
\hline
\end{tabular}


According to Table 4, the majority of in vivo studies utilized NTP-induced immune cell modulation in some kind of immunotherapeutic approach. Indeed, NTP technology has been shown to be effective in immunoprotection against malignant melanoma [46] or as a potential adjuvant melanoma treatment via induction of immunogenic cell death (ICD) [48]. Overall, this analysis of in vitro and in vivo studies on the immunomodulatory effects of NTP shows that NTP has the potential in mediating the activity of immune cells. Such modulation of immune cells functions by NTP shows the potential to effectively control tumor growth at least in a mouse model of melanoma [46]. However, the molecular mechanisms of NTP-induced immune cell modulation remain unclear. There is a need for future studies to elucidate this gap in knowledge.

\section{Challenges in Deciphering Molecular Targets of NTP Action}

Contrary to previous reviews on biomedical applications of NTP, we would like to add a bit of critical analysis here. In judging results and making straightforward conclusions, we have to be very careful. Biomedical literature faces rising concerns that a substantial fraction of published research findings are false $[149,150]$. Overall, modern science is hampered by the issue of reproducibility of the research [151,152]. Specifically, in many cases, biomedical studies take shortcuts around the used methodology, resulting in devastating consequences $[153,154]$. It is estimated, that low reproducibility rates within life science research result in approximately $\$ 28$ billion USD/year being wasted on irreproducible preclinical research in the United States [155]. Thus, it is an imperative to critically assess potential treatment modalities.

Although NTP shows great potential, we have identified certain pitfalls in the current research, which create challenges in the identification of molecular mechanisms of NTP action. Importantly, in a long run strategy such challenges may result in the clinical fail of the treatment. Further, we briefly describe the major challenges in NTP-immune cell modulation. In Section 2, we summarized that NTP sources vary in used gas composition power, discharge voltage, gas flow rate, jet length, and voltage frequencies, which in turn dramatically affect the chemistry of NTP $[24,30,33,45,54,55]$. This variability in design and physicochemical composition of NTP greatly affect biological outcome modulated by NTP. In fact, NTP shows sometimes bewildering biological effects. As an example, from Tables 3 and 4, one can see, that there is a huge variability in the type of device, gas composition, voltage and frequency. Bearing in mind how NTP-triggered biological effects vary, it is very difficult to compare isolated studies. Thus, there is a significant challenge in the standardization of NTP treatments. In order to reasonably compare different NTP effects in different laboratories, there is an unmet need for standardization of the treatment protocols. Just to illustrate how cautious one has to be, here is an example of how a very tiny handling protocol alteration may lead to irreproducible results [156]. Two laboratories could not reproduce each other's cell-sorting profiles of breast cells, notwithstanding the fact that they utilized identical methods, reagents, and even specimens [156]. After long-term struggle, the researchers realized that the stirring procedure made a difference [156].

Another challenge lies in the usage of cell lines. From Table 3, it is apparent that the majority of studies, for instance, are done utilizing the THP-1 cell line. In fact, monocytic cell lines of varying degrees of differentiation represent a very nice initial model that can substitute primary innate immune cells, e.g., macrophages in vitro [157-159]. In order to closer mimic macrophages features, differentiation protocols using phorbol-12-myristate-13-acetate (PMA) or 1,25-dihydroxyvitamin $\mathrm{D}_{3}$ are frequently used. Indeed, such differentiation may recapitulate certain macrophage functions [160,161]. However, the phenotype of the differentiated cells is very different when compared with primary cells, reflecting differences in gene expression and altered cellular functions $[160,162]$. Thus, a broad involvement of human primary cells is crucial for deciphering mechanisms of NTP-induced immunomodulatory effects.

Further, despite the fact that trends in biomedical research are changing, to get US Food and Drug Administration (FDA) treatment approval, it is not necessary to identify the mechanism(s) of treatment action $[52,53]$. However, we should remember that such an approach might lead to severe failure at the final stages of clinical trials [52,53]. In fact, deciphering the mechanism of treatment action really matters 
and starts with target identification [52]. Importantly, target verification requires a thorough biological understanding [163]. As a result, target verification contributes greatly to a reduction in the rate of clinical failure of a treatment in early clinical development [163]. Knowledge of the mechanism by which a drug/treatment acts greatly helps to optimize the therapeutic window of a treatment [164]. When the mechanism of action is known, it is possible to perform better dosing for a patient via monitoring the drug's effects on the target pathway $[52,53,164]$. Knowledge of how a drug/treatment works is essential to stratify clinical trials optimizing patient enrollment $[52,53,164]$. In case of developing a treatment that utilizes cytotoxic or cytostatic effects (e.g., anticancer or antibacterial), understanding the mechanisms of resistance and action at the molecular level is essential to develop a therapeutic modality capable of preventing or blocking resistance effect [165]. It is true that studies revealing molecular mechanisms of treatment action are costly, time-consuming, and require a lot of effort. After all, this knowledge pays off in the long run by increasing the chances for drug approval and saving money and time at the stage of clinical trials [52]. However, most importantly, it saves the lives of patients [52]. Therefore, it is very important to identify cellular and molecular mechanisms of NTP action. We have to admit that several studies have been undertaken (Tables 3 and 4). However, there is a significant lack of research that utilizes gene-editing techniques to verify obtained findings. Indeed, the genetic background of cells may dramatically influence the susceptibility of cells to NTP treatment [37]. The cases of such research are unfortunately isolated. We have to grasp the necessary information from replicated robust studies to achieve effective NTP-based treatments. Thus, we definitely need more studies that reveal the underlying molecular mechanisms of NTP-induced immunomodulatory effects. Only the knowledge of the spatiotemporal mechanisms of the NTP-induced effects will enable the deliberate exploitation of such signals, e.g., for the potential clinical translation. Additionally, we need to realize our current misunderstandings on NTP-based treatments. This will put NTP in a better position to become a progressive treatment modality.

\section{Conclusions}

Concluding our review, we would like to emphasize that NTP really has great potential in various biomedical applications and particularly as an immunomodulatory effector. From the cellular biological point of view, the field is still in its infancy. The pitfalls that the NTP field faces are typical for developing research directions. Overall, in recent years, pharmaceutical drug research and development show declining output in terms of the number of new drugs [166]. However, as scientists, we must remember that the main goal of our research is to finally help patients by developing clinically useful treatments [167].

In this review, we summarized critical challenges that have to be addressed by the researchers in order to make NTP a reliable clinical treatment. We hope that our critical analysis will help researchers to overcome the aforementioned challenges and develop better controlled, safer, and more robust NTP-based treatment modalities.

Author Contributions: Conceptualization, O.L.; methodology, B.S., A.F., A.D., and M.U.; validation, M.L., Š.K., and A.D.; formal analysis, O.L.; investigation, B.S., A.F., A.D., and M.U.; resources, A.D.; data curation, O.L.; writing-original draft preparation, O.L.; writing-review and editing, B.S., A.F., A.D., M.U., M.L., and Š.K.; visualization, O.L. and A.F.; supervision, O.L.; project administration, O.L.; funding acquisition, A.D. All authors have read and agreed to the published version of the manuscript.

Funding: The work is supported by Operational Programme Research, Development and Education financed by the European Structural and Investment Funds and the Czech Ministry of Education, Youth and Sports (Project No. SOLID21-CZ.02.1.01/0.0/0.0/16_019/0000760). Supported by the Ministry of Industry and Trade of the Czech Republic: FV10081.

Acknowledgments: The authors acknowledge the MH CZ-DRO Institute for Clinical and Experimental Medicine-IKEM, IN 00023001. Graphical abstract was created using BioRender.com.

Conflicts of Interest: The authors declare no conflict of interest. 


\section{Abbreviations}

\begin{tabular}{|c|c|}
\hline NTP & Non-thermal plasma \\
\hline ROS & Reactive oxygen species \\
\hline RNS & Reactive nitrogen species \\
\hline DBD & Dielectric barrier discharge \\
\hline APPJ & Atmospheric pressure plasma jet \\
\hline ROI & Reactive oxygen intermediates \\
\hline CPGs & Clinical Practice Guidelines \\
\hline ICD & Immunogenic cell death \\
\hline ATP & Adenosine triphosphate \\
\hline ATF4 & Activating transcription factor 4 \\
\hline CAT & Catalase \\
\hline CCL4 & Carbon tetrachloride \\
\hline CXCL1 & C-X-C motif ligand 1 \\
\hline ER & Endoplasmic reticulum \\
\hline HMOX & Heme oxygenase \\
\hline HSP27 & Heat shock protein 27 \\
\hline iNOS & Nitric oxide synthase \\
\hline MBMDc & Murine bone-marrow derived cells \\
\hline MCP1 & Monocyte chemoattractant protein \\
\hline MDM & Monocyte-derived macrophages \\
\hline NET & Neutrophil extracellular traps \\
\hline NETosis & Neutrophil extracellular traps activation and release \\
\hline NOS2 & Nitric oxide synthase \\
\hline PBMCs & Peripheral blood mononuclear cells \\
\hline PMA & Phorbol-12-myristate-13-acetate \\
\hline SOD1 & Superoxide dismutase 1 \\
\hline STC2 & Stanniocalcin-2 \\
\hline TAM & Tumor-associated macrophages \\
\hline TGF $\beta$ & Transforming growth factor beta \\
\hline $\mathrm{TNF} \alpha$ & Tumor necrosis factor alpha \\
\hline VBN & Venous blood neutrophils \\
\hline $\mathrm{AD}$ & Atopic dermatitis \\
\hline BMDC & Bone marrow-derived dendritic cells \\
\hline CCL17 & Chemokine (C-C motif) ligand 17 \\
\hline CRT & Calreticulin \\
\hline DCs & Dendritic cells \\
\hline GM-CSF & Granulocyte-macrophage colony-stimulating factor \\
\hline HDM & House dust mite \\
\hline HMGB1 & High mobility group protein B1 \\
\hline HSP70 & Heat shock protein 70 \\
\hline $\operatorname{IFN} \gamma$ & Interferon gamma \\
\hline IL & Interleukin \\
\hline MHC II & Major histocompatibility complex class II \\
\hline NF-кB & Nuclear factor kappa B \\
\hline NK cells & Natural killer cells \\
\hline PBS & Phosphate-buffered saline \\
\hline TSLP & Thymic stromal lymphopoietin \\
\hline
\end{tabular}

\section{References}

1. Keevil, S.F. Physics and medicine: A historical perspective. Lancet 2012, 379, 1517-1524. [CrossRef]

2. Melzer, A.; Cochran, S.; Prentice, P.; MacDonald, M.P.; Wang, Z.; Cuschieri, A. The importance of physics to progress in medical treatment. Lancet 2012, 379, 1534-1543. [CrossRef] 
3. Babaeva, N.Y.; Naidis, G.V. Modeling of plasmas for biomedicine. Trends Biotechnol. 2018, 36, $603-614$. [CrossRef] [PubMed]

4. Keidar, M.; Yan, D.; Beilis, I.I.; Trink, B.; Sherman, J.H. Plasmas for treating cancer: Opportunities for adaptive and self-adaptive approaches. Trends Biotechnol. 2018, 36, 586-593. [CrossRef] [PubMed]

5. Szili, E.J.; Hong, S.H.; Oh, J.S.; Gaur, N.; Short, R.D. Tracking the penetration of plasma reactive species in tissue models. Trends Biotechnol. 2018, 36, 594-602. [CrossRef]

6. Sung, S.J.; Huh, J.B.; Yun, M.J.; Chang, B.M.; Jeong, C.M.; Jeon, Y.C. Sterilization effect of atmospheric pressure non-thermal air plasma on dental instruments. J. Adv. Prosthodont. 2013, 5, 2-8. [CrossRef]

7. Scholtz, V.; Pazlarova, J.; Souskova, H.; Khun, J.; Julak, J. Nonthermal plasma-A tool for decontamination and disinfection. Biotechnol. Adv. 2015, 33, 1108-1119. [CrossRef]

8. De Geyter, N.; Morent, R. Nonthermal plasma sterilization of living and nonliving surfaces. Annu. Rev. Biomed. Eng. 2012, 14, 255-274. [CrossRef]

9. Kubinova, S.; Zaviskova, K.; Uherkova, L.; Zablotskii, V.; Churpita, O.; Lunov, O.; Dejneka, A. Non-thermal air plasma promotes the healing of acute skin wounds in rats. Sci. Rep. 2017, 7, 45183. [CrossRef]

10. Chatraie, M.; Torkaman, G.; Khani, M.; Salehi, H.; Shokri, B. In vivo study of non-invasive effects of non-thermal plasma in pressure ulcer treatment. Sci. Rep. 2018, 8, 5621. [CrossRef]

11. Gilmore, B.F.; Flynn, P.B.; O’Brien, S.; Hickok, N.; Freeman, T.; Bourke, P. Cold plasmas for biofilm control: Opportunities and challenges. Trends Biotechnol. 2018, 36, 627-638. [CrossRef] [PubMed]

12. Smolkova, B.; Uzhytchak, M.; Lynnyk, A.; Kubinova, S.; Dejneka, A.; Lunov, O. A critical review on selected external physical cues and modulation of cell behavior: Magnetic nanoparticles, non-thermal plasma and lasers. J. Funct. Biomater. 2018, 10, 2. [CrossRef]

13. Lunov, O.; Zablotskii, V.; Churpita, O.; Jager, A.; Polivka, L.; Sykova, E.; Dejneka, A.; Kubinova, S. The interplay between biological and physical scenarios of bacterial death induced by non-thermal plasma. Biomaterials 2016, 82, 71-83. [CrossRef] [PubMed]

14. Lunov, O.; Churpita, O.; Zablotskii, V.; Deyneka, I.G.; Meshkovskii, I.K.; Jager, A.; Sykova, E.; Kubinova, S.; Dejneka, A. Non-thermal plasma mills bacteria: Scanning electron microscopy observations. Appl. Phys. Lett. 2015, 106, 053703. [CrossRef]

15. Rupf, S.; Lehmann, A.; Hannig, M.; Schafer, B.; Schubert, A.; Feldmann, U.; Schindler, A. Killing of adherent oral microbes by a non-thermal atmospheric plasma jet. J. Med. Microbiol. 2010, 59, 206-212. [CrossRef] [PubMed]

16. Kalghatgi, S.U.; Fridman, G.; Cooper, M.; Nagaraj, G.; Peddinghaus, M.; Balasubramanian, M.; Vasilets, V.N.; Gutsol, A.F.; Fridman, A.; Friedman, G. Mechanism of blood coagulation by nonthermal atmospheric pressure dielectric barrier discharge plasma. IEEE Trans. Plasma Sci. 2007, 35, 1559-1566. [CrossRef]

17. Gweon, B.; Kim, H.; Kim, K.; Kim, M.; Shim, E.; Kim, S.; Choe, W.; Shin, J.H. Suppression of angiogenesis by atmospheric pressure plasma in human aortic endothelial cells. Appl. Phys. Lett. 2014, 104, 133701. [CrossRef]

18. Bekeschus, S.; Ressel, V.; Freund, E.; Gelbrich, N.; Mustea, A.; Stope, M.B. Gas plasma-treated prostate cancer cells augment myeloid cell activity and cytotoxicity. Antioxidants 2020, 9, 323. [CrossRef]

19. Wolff, C.M.; Kolb, J.F.; Weltmann, K.D.; von Woedtke, T.; Bekeschus, S. Combination treatment with cold physical plasma and pulsed electric fields augments ROS production and cytotoxicity in lymphoma. Cancers 2020, 12, 845. [CrossRef]

20. Sarangapani, C.; Patange, A.; Bourke, P.; Keener, K.; Cullen, P.J. Recent advances in the application of cold plasma technology in foods. Annu. Rev. Food Sci. Technol. 2018, 9, 609-629. [CrossRef]

21. Lopez, M.; Calvo, T.; Prieto, M.; Mugica-Vidal, R.; Muro-Fraguas, I.; Alba-Elias, F.; Alvarez-Ordonez, A. A review on non-thermal atmospheric plasma for food preservation: Mode of action, determinants of effectiveness, and applications. Front. Microbiol. 2019, 10, 622. [CrossRef] [PubMed]

22. Arjunan, K.P.; Friedman, G.; Fridman, A.; Clyne, A.M. Non-thermal dielectric barrier discharge plasma induces angiogenesis through reactive oxygen species. J. R. Soc. Interface 2012, 9, 147-157. [CrossRef]

23. Bekeschus, S.; Schmidt, A.; Weltmann, K.D.; von Woedtke, T. The plasma jet kINPen-A powerful tool for wound healing. Clin. Plasma Med. 2016, 4, 19-28. [CrossRef]

24. Weltmann, K.D.; von Woedtke, T. Plasma medicine-current state of research and medical application. Plasma Phys. Control. Fusion 2017, 59, 014031. [CrossRef] 
25. Isbary, G.; Morfill, G.; Schmidt, H.U.; Georgi, M.; Ramrath, K.; Heinlin, J.; Karrer, S.; Landthaler, M.; Shimizu, T.; Steffes, B.; et al. A first prospective randomized controlled trial to decrease bacterial load using cold atmospheric argon plasma on chronic wounds in patients. Br. J. Dermatol. 2010, 163, 78-82. [CrossRef]

26. Isbary, G.; Heinlin, J.; Shimizu, T.; Zimmermann, J.L.; Morfill, G.; Schmidt, H.U.; Monetti, R.; Steffes, B.; Bunk, W.; Li, Y.; et al. Successful and safe use of 2 min cold atmospheric argon plasma in chronic wounds: Results of a randomized controlled trial. Br. J. Dermatol. 2012, 167, 404-410. [CrossRef]

27. Heinlin, J.; Zimmermann, J.L.; Zeman, F.; Bunk, W.; Isbary, G.; Landthaler, M.; Maisch, T.; Monetti, R.; Morfill, G.; Shimizu, T.; et al. Randomized placebo-controlled human pilot study of cold atmospheric argon plasma on skin graft donor sites. Wound Repair Regen. 2013, 21, 800-807. [CrossRef]

28. Daeschlein, G.; Napp, M.; Lutze, S.; Arnold, A.; von Podewils, S.; Guembel, D.; Junger, M. Skin and wound decontamination of multidrug-resistant bacteria by cold atmospheric plasma coagulation. J. Dtsch. Dermatol. Ges. 2015, 13, 143-150. [CrossRef]

29. Von Woedtke, T.; Metelmann, H.R.; Weltmann, K.D. Clinical plasma medicine: State and perspectives of in vivo application of cold atmospheric plasma. Contrib. Plasma Phys. 2014, 54, 104-117. [CrossRef]

30. Von Woedtke, T.; Reuter, S.; Masur, K.; Weltmann, K.D. Plasmas for medicine. Phys. Rep. 2013, 530, $291-320$. [CrossRef]

31. Heinlin, J.; Isbary, G.; Stolz, W.; Morfill, G.; Landthaler, M.; Shimizu, T.; Steffes, B.; Nosenko, T.; Zimmermann, J.; Karrer, S. Plasma applications in medicine with a special focus on dermatology. J. Eur. Acad. Dermatol. Venereol. 2011, 25, 1-11. [CrossRef] [PubMed]

32. Lunov, O. Plasma will. Br. J. Dermatol. 2016, 174, 486-487. [CrossRef] [PubMed]

33. Lu, X.; Naidis, G.V.; Laroussi, M.; Reuter, S.; Graves, D.B.; Ostrikov, K. Reactive species in non-equilibrium atmospheric-pressure plasmas: Generation, transport, and biological effects. Phys. Rep. 2016, 630, 1-84. [CrossRef]

34. Ishaq, M.; Evans, M.M.; Ostrikov, K.K. Effect of atmospheric gas plasmas on cancer cell signaling. Int. J. Cancer 2014, 134, 1517-1528. [CrossRef] [PubMed]

35. Jang, J.Y.; Hong, Y.J.; Lim, J.; Choi, J.S.; Choi, E.H.; Kang, S.; Rhim, H. Cold atmospheric plasma (CAP), a novel physicochemical source, induces neural differentiation through cross-talk between the specific RONS cascade and Trk/Ras/ERK signaling pathway. Biomaterials 2018, 156, 258-273. [CrossRef] [PubMed]

36. Privat-Maldonado, A.; Schmidt, A.; Lin, A.; Weltmann, K.D.; Wende, K.; Bogaerts, A.; Bekeschus, S. ROS from physical plasmas: Redox chemistry for biomedical therapy. Oxid. Med. Cell. Longev. 2019, 2019, 9062098. [CrossRef] [PubMed]

37. Smolkova, B.; Lunova, M.; Lynnyk, A.; Uzhytchak, M.; Churpita, O.; Jirsa, M.; Kubinova, S.; Lunov, O.; Dejneka, A. Non-thermal plasma, as a new physicochemical source, to induce redox imbalance and subsequent cell death in liver cancer cell lines. Cell. Physiol. Biochem. 2019, 52, 119-140.

38. Giorgio, M.; Trinei, M.; Migliaccio, E.; Pelicci, P.G. Hydrogen peroxide: A metabolic by-product or a common mediator of ageing signals? Nat. Rev. Mol. Cell Biol. 2007, 8, 722-728. [CrossRef]

39. Reth, M. Hydrogen peroxide as second messenger in lymphocyte activation. Nat. Immunol. 2002, 3, 1129-1134. [CrossRef]

40. Holmstrom, K.M.; Finkel, T. Cellular mechanisms and physiological consequences of redox-dependent signalling. Nat. Rev. Mol. Cell Biol. 2014, 15, 411-421. [CrossRef]

41. Schieber, M.; Chandel, N.S. ROS function in redox signaling and oxidative stress. Curr. Biol. 2014, 24, R453-R462. [CrossRef]

42. D'Autreaux, B.; Toledano, M.B. ROS as signalling molecules: Mechanisms that generate specificity in ROS homeostasis. Nat. Rev. Mol. Cell Biol. 2007, 8, 813-824. [CrossRef] [PubMed]

43. Mittler, R.; Vanderauwera, S.; Suzuki, N.; Miller, G.; Tognetti, V.B.; Vandepoele, K.; Gollery, M.; Shulaev, V.; Van Breusegem, F. ROS signaling: The new wave? Trends Plant. Sci. 2011, 16, 300-309. [CrossRef] [PubMed]

44. Nathan, C.; Cunningham-Bussel, A. Beyond oxidative stress: An immunologist's guide to reactive oxygen species. Nat. Rev. Immunol. 2013, 13, 349-361. [CrossRef] [PubMed]

45. Kong, M.G.; Kroesen, G.; Morfill, G.; Nosenko, T.; Shimizu, T.; van Dijk, J.; Zimmermann, J.L. Plasma medicine: An introductory review. New J. Phys. 2009, 11, 115012. [CrossRef]

46. Bekeschus, S.; Clemen, R.; Niessner, F.; Sagwal, S.K.; Freund, E.; Schmidt, A. Medical gas plasma jet technology targets murine melanoma in an immunogenic fashion. Adv. Sci. 2020, 7, 1903438. [CrossRef] [PubMed] 
47. Lin, A.G.; Xiang, B.; Merlino, D.J.; Baybutt, T.R.; Sahu, J.; Fridman, A.; Snook, A.E.; Miller, V. Non-thermal plasma induces immunogenic cell death in vivo in murine CT26 colorectal tumors. Oncoimmunology 2018, 7, e1484978. [CrossRef]

48. Lin, A.; Gorbanev, Y.; De Backer, J.; Van Loenhout, J.; Van Boxem, W.; Lemiere, F.; Cos, P.; Dewilde, S.; Smits, E.; Bogaerts, A. Non-thermal plasma as a unique delivery system of short-lived reactive oxygen and nitrogen species for immunogenic cell death in melanoma cells. Adv. Sci. 2019, 6, 1802062. [CrossRef]

49. Fanelli, D.; Costas, R.; Lariviere, V. Misconduct policies, academic culture and career stage, not gender or pressures to publish, affect scientific integrity. PLoS ONE 2015, 10, e0127556. [CrossRef]

50. Morrison, S.J. Time to do something about reproducibility. eLife 2014, 3, e03981. [CrossRef]

51. Stern, A.M.; Casadevall, A.; Steen, R.G.; Fang, F.C. Financial costs and personal consequences of research misconduct resulting in retracted publications. eLife 2014, 3, e02956. [CrossRef]

52. Mechanism matters. Nat. Med. 2010, 16, 347. [CrossRef]

53. Ehrenstein, M.R.; Mauri, C. If the treatment works, do we need to know why?: The promise of immunotherapy for experimental medicine. J. Exp. Med. 2007, 204, 2249-2252. [CrossRef]

54. Isbary, G.; Shimizu, T.; Li, Y.F.; Stolz, W.; Thomas, H.M.; Morfill, G.E.; Zimmermann, J.L. Cold atmospheric plasma devices for medical issues. Expert Rev. Med. Devices 2013, 10, 367-377. [CrossRef]

55. Fridman, G.; Friedman, G.; Gutsol, A.; Shekhter, A.B.; Vasilets, V.N.; Fridman, A. Applied plasma medicine. Plasma Process. Polym. 2008, 5, 503-533. [CrossRef]

56. Lu, X.; Laroussi, M.; Puech, V. On atmospheric-pressure non-equilibrium plasma jets and plasma bullets. Plasma Sources Sci. Technol. 2012, 21, 034005. [CrossRef]

57. Ehlbeck, J.; Schnabel, U.; Polak, M.; Winter, J.; von Woedtke, T.; Brandenburg, R.; von dem Hagen, T.; Weltmann, K.D. Low temperature atmospheric pressure plasma sources for microbial decontamination. J. Phys. D Appl. Phys. 2011, 44, 013002. [CrossRef]

58. Fridman, G.; Peddinghaus, M.; Ayan, H.; Fridman, A.; Balasubramanian, M.; Gutsol, A.; Brooks, A.; Friedman, G. Blood coagulation and living tissue sterilization by floating-electrode dielectric barrier discharge in air. Plasma Chem. Plasma Process. 2006, 26, 425-442. [CrossRef]

59. Dobrynin, D.; Fridman, G.; Friedman, G.; Fridman, A. Physical and biological mechanisms of direct plasma interaction with living tissue. New J. Phys. 2009, 11, 115020. [CrossRef]

60. Al-Abduly, A.; Christensen, P. An in situ and downstream study of non-thermal plasma chemistry in an air fed dielectric barrier discharge (DBD). Plasma Sources Sci. Technol. 2015, 24, 065006. [CrossRef]

61. Attri, P.; Kim, Y.H.; Park, D.H.; Park, J.H.; Hong, Y.J.; Uhm, H.S.; Kim, K.N.; Fridman, A.; Choi, E.H. Generation mechanism of hydroxyl radical species and its lifetime prediction during the plasma-initiated ultraviolet (UV) photolysis. Sci. Rep. 2015, 5, 9332. [CrossRef]

62. Rumbach, P.; Witzke, M.; Sankaran, R.M.; Go, D.B. Decoupling interfacial reactions between plasmas and liquids: Charge transfer vs. plasma neutral reactions. J. Am. Chem. Soc. 2013, 135, 16264-16267. [CrossRef]

63. Jablonowski, H.; von Woedtke, T. Research on plasma medicine-relevant plasma-liquid interaction: What happened in the past five years? Clin. Plasma Med. 2015, 3, 42-52. [CrossRef]

64. Girard, P.M.; Arbabian, A.; Fleury, M.; Bauville, G.; Puech, V.; Dutreix, M.; Sousa, J.S. Synergistic effect of $\mathrm{H}_{2} \mathrm{O}_{2}$ and $\mathrm{NO}_{2}$ in cell death induced by cold atmospheric He plasma. Sci. Rep. 2016, 6, 29098. [CrossRef]

65. Shiraiwa, M.; Sosedova, Y.; Rouviere, A.; Yang, H.; Zhang, Y.; Abbatt, J.P.; Ammann, M.; Poschl, U. The role of long-lived reactive oxygen intermediates in the reaction of ozone with aerosol particles. Nat. Chem. 2011, 3, 291-295. [CrossRef]

66. Endre, J.S.; James, W.B.; Robert, D.S. A 'tissue model' to study the plasma delivery of reactive oxygen species. J. Phys. D Appl. Phys. 2014, 47, 152002.

67. Lackmann, J.W.; Wende, K.; Verlackt, C.; Golda, J.; Volzke, J.; Kogelheide, F.; Held, J.; Bekeschus, S.; Bogaerts, A.; Schulz-von der Gathen, V.; et al. Chemical fingerprints of cold physical plasmas-An experimental and computational study using cysteine as tracer compound. Sci. Rep. 2018, 8, 7736. [CrossRef]

68. Arndt, S.; Unger, P.; Berneburg, M.; Bosserhoff, A.K.; Karrer, S. Cold atmospheric plasma (CAP) activates angiogenesis-related molecules in skin keratinocytes, fibroblasts and endothelial cells and improves wound angiogenesis in an autocrine and paracrine mode. J. Dermatol. Sci. 2018, 89, 181-190. [CrossRef]

69. Kalghatgi, S.; Friedman, G.; Fridman, A.; Clyne, A.M. Endothelial cell proliferation is enhanced by low dose non-thermal plasma through fibroblast growth factor-2 release. Ann. Biomed. Eng. 2010, 38, 748-757. [CrossRef] 
70. Kalghatgi, S.; Kelly, C.M.; Cerchar, E.; Torabi, B.; Alekseev, O.; Fridman, A.; Friedman, G.; Azizkhan-Clifford, J. Effects of non-thermal plasma on mammalian cells. PLOS ONE 2011, 6, e16270. [CrossRef]

71. Gweon, B.; Kim, D.; Kim, D.B.; Jung, H.; Choe, W.; Shin, J.H. Plasma effects on subcellular structures. Appl. Phys. Lett. 2010, 96, 101501. [CrossRef]

72. Kim, G.J.; Kim, W.; Kim, K.T.; Lee, J.K. DNA damage and mitochondria dysfunction in cell apoptosis induced by nonthermal air plasma. Appl. Phys. Lett. 2010, 96, 021502. [CrossRef]

73. Ahn, H.J.; Kim, K.I.; Hoan, N.N.; Kim, C.H.; Moon, E.; Choi, K.S.; Yang, S.S.; Lee, J.S. Targeting cancer cells with reactive oxygen and nitrogen species generated by atmospheric-pressure air plasma. PLoS ONE 2014, 9, e86173. [CrossRef]

74. Ahn, H.J.; Kim, K.I.; Kim, G.; Moon, E.; Yang, S.S.; Lee, J.S. Atmospheric-pressure plasma jet induces apoptosis involving mitochondria via generation of free radicals. PLoS ONE 2011, 6, e28154. [CrossRef]

75. Lunov, O.; Zablotskii, V.; Churpita, O.; Lunova, M.; Jirsa, M.; Dejneka, A.; Kubinova, S. Chemically different non-thermal plasmas target distinct cell death pathways. Sci. Rep. 2017, 7, 600. [CrossRef]

76. Lunov, O.; Zablotskii, V.; Churpita, O.; Jaeger, A.; Polivka, L.; Sykova, E.; Terebova, N.; Kulikov, A.; Kubinova, S.; Dejneka, A. Towards the understanding of non-thermal air plasma action: Effects on bacteria and fibroblasts. RSC Adv. 2016, 6, 25286-25292. [CrossRef]

77. Park, J.Y.; Park, S.; Choe, W.; Yong, H.I.; Jo, C.; Kim, K. Plasma-functionalized solution: A potent antimicrobial agent for biomedical applications from antibacterial therapeutics to biomaterial surface engineering. ACS Appl. Mater. Interfaces 2017, 9, 43470-43477. [CrossRef]

78. Metelmann, H.R.; Seebauer, C.; Miller, V.; Fridman, A.; Bauer, G.; Graves, D.B.; Pouvesle, J.M.; Rutkowski, R.; Schuster, M.; Bekeschus, S.; et al. Clinical experience with cold plasma in the treatment of locally advanced head and neck cancer. Clin. Plasma Med. 2018, 9, 6-13. [CrossRef]

79. Jablonowski, L.; Kocher, T.; Schindler, A.; Muller, K.; Dombrowski, F.; von Woedtke, T.; Arnold, T.; Lehmann, A.; Rupf, S.; Evert, M.; et al. Side effects by oral application of atmospheric pressure plasma on the mucosa in mice. PLoS ONE 2019, 14, e0215099. [CrossRef]

80. Schuster, M.; Rutkowski, R.; Hauschild, A.; Shojaei, R.K.; von Woedtke, T.; Rana, A.; Bauer, G.; Metelmann, P.; Seebauer, C. Side effects in cold plasma treatment of advanced oral cancer-clinical data and biological interpretation. Clin. Plasma Med. 2018, 10, 9-15. [CrossRef]

81. Coleman, J.J.; Ferner, R.E.; Evans, S.J. Monitoring for adverse drug reactions. Br. J. Clin. Pharmacol. 2006, 61, 371-378. [CrossRef]

82. Coleman, J.J.; Pontefract, S.K. Adverse drug reactions. Clin. Med. 2016, 16, 481-485. [CrossRef]

83. McDowell, S.E.; Thomas, S.K.; Coleman, J.J.; Aronson, J.K.; Ferner, R.E. A practical guide to monitoring for adverse drug reactions during antihypertensive drug therapy. J. R. Soc. Med. 2013, 106, 87-95. [CrossRef]

84. Arjunan, K.P.; Sharma, V.K.; Ptasinska, S. Effects of atmospheric pressure plasmas on isolated and cellular DNA-a review. Int. J. Mol. Sci. 2015, 16, 2971-3016. [CrossRef]

85. Wende, K.; Bekeschus, S.; Schmidt, A.; Jatsch, L.; Hasse, S.; Weltmann, K.D.; Masur, K.; von Woedtke, T. Risk assessment of a cold argon plasma jet in respect to its mutagenicity. Mutat. Res. Genet. Toxicol. Environ. 2016, 798-799, 48-54. [CrossRef]

86. Fiers, W.; Beyaert, R.; Declercq, W.; Vandenabeele, P. More than one way to die: Apoptosis, necrosis and reactive oxygen damage. Oncogene 1999, 18, 7719-7730. [CrossRef]

87. Linkermann, A.; Green, D.R. Necroptosis. N. Engl. J. Med. 2014, 370, 455-465. [CrossRef]

88. Marino, G.; Niso-Santano, M.; Baehrecke, E.H.; Kroemer, G. Self-consumption: The interplay of autophagy and apoptosis. Nat. Rev. Mol. Cell Biol. 2014, 15, 81-94. [CrossRef]

89. Temkin, V.; Karin, M. From death receptor to reactive oxygen species and c-Jun N-terminal protein kinase: The receptor-interacting protein 1 odyssey. Immunol. Rev. 2007, 220, 8-21. [CrossRef]

90. Jin, J.; Sklar, G.E.; Min Sen Oh, V.; Chuen Li, S. Factors affecting therapeutic compliance: A review from the patient's perspective. Ther. Clin. Risk Manag. 2008, 4, 269-286.

91. Ulrich, C.; Kluschke, F.; Patzelt, A.; Vandersee, S.; Czaika, V.A.; Richter, H.; Bob, A.; von Hutten, J.; Painsi, C.; Hugel, R.; et al. Clinical use of cold atmospheric pressure argon plasma in chronic leg ulcers: A pilot study. J. Wound Care 2015, 24, 196-203. [CrossRef]

92. Emmert, S.; Brehmer, F.; Hänßle, H.; Helmke, A.; Mertens, N.; Ahmed, R.; Simon, D.; Wandke, D.; Maus-Friedrichs, W.; Däschlein, G.; et al. Atmospheric pressure plasma in dermatology: Ulcus treatment and much more. Clin. Plasma Med. 2013, 1, 24-29. [CrossRef] 
93. Isbary, G.; Shimizu, T.; Zimmermann, J.L.; Heinlin, J.; Al-Zaabi, S.; Rechfeld, M.; Morfill, G.E.; Karrer, S.; Stolz, W. Randomized placebo-controlled clinical trial showed cold atmospheric argon plasma relieved acute pain and accelerated healing in herpes zoster. Clin. Plasma Med. 2014, 2, 50-55. [CrossRef]

94. Klebes, M.; Lademann, J.; Philipp, S.; Ulrich, C.; Patzelt, A.; Ulmer, M.; Kluschke, F.; Kramer, A.; Weltmann, K.D.; Sterry, W.; et al. Effects of tissue-tolerable plasma on psoriasis vulgaris treatment compared to conventional local treatment: A pilot study. Clin. Plasma Med. 2014, 2, 22-27. [CrossRef]

95. Isbary, G.; Zimmermann, J.L.; Shimizu, T.; Li, Y.F.; Morfill, G.E.; Thomas, H.M.; Steffes, B.; Heinlin, J.; Karrer, S.; Stolz, W. Non-thermal plasma-More than five years of clinical experience. Clin. Plasma Med. 2013, 1, 19-23. [CrossRef]

96. Freund, E.; Liedtke, K.R.; van der Linde, J.; Metelmann, H.R.; Heidecke, C.D.; Partecke, L.I.; Bekeschus, S. Physical plasma-treated saline promotes an immunogenic phenotype in CT26 colon cancer cells in vitro and in vivo. Sci. Rep. 2019, 9, 634. [CrossRef]

97. Dickersin, K.; Straus, S.E.; Bero, L.A. Evidence based medicine: Increasing, not dictating, choice. BMJ 2007, 334 (Suppl. 1), s10. [CrossRef]

98. Karagiannis, T. The importance of applying evidence-based medicine in clinical practice. In Management of Hypertension: Current Practice and the Application of Landmark Trials; Papademetriou, V., Andreadis, E.A., Geladari, C., Eds.; Springer International Publishing: Cham, Switzerland, 2019; pp. 3-17. [CrossRef]

99. Djulbegovic, B.; Guyatt, G.H. Progress in evidence-based medicine: A quarter century on. Lancet 2017, 390, 415-423. [CrossRef]

100. Ben-Shlomo, Y. Evidence based medicine: Does it make a difference? Numerophobia may be a problem in adopting evidence based medicine. BMJ 2005, 330, 93.

101. Rosenberg, W.; Donald, A. Evidence based medicine: An approach to clinical problem-solving. BMJ 1995, 310, 1122-1126. [CrossRef]

102. Sabri, A.A.; Qayyum, M.A. The problem of evidence-based medicine in developing countries. CMAJ 2006, 175, 62. [CrossRef]

103. Woolf, S.H.; Grol, R.; Hutchinson, A.; Eccles, M.; Grimshaw, J. Clinical guidelines: Potential benefits, limitations, and harms of clinical guidelines. BMJ 1999, 318, 527-530. [CrossRef]

104. Kredo, T.; Bernhardsson, S.; Machingaidze, S.; Young, T.; Louw, Q.; Ochodo, E.; Grimmer, K. Guide to clinical practice guidelines: The current state of play. Int. J. Qual. Health Care 2016, 28, 122-128. [CrossRef]

105. Ho, P.M.; Peterson, P.N.; Masoudi, F.A. Evaluating the evidence-Is there a rigid hierarchy? Circulation 2008, 118, 1675-1684. [CrossRef]

106. Yetley, E.A.; MacFarlane, A.J.; Greene-Finestone, L.S.; Garza, C.; Ard, J.D.; Atkinson, S.A.; Bier, D.M.; Carriquiry, A.L.; Harlan, W.R.; Hattis, D.; et al. Options for basing Dietary Reference Intakes (DRIs) on chronic disease endpoints: Report from a joint US-/Canadian-sponsored working group. Am. J. Clin. Nutr. 2017, 105, 249S-285S. [CrossRef]

107. Atkins, D.; Briss, P.A.; Eccles, M.; Flottorp, S.; Guyatt, G.H.; Harbour, R.T.; Hill, S.; Jaeschke, R.; Liberati, A.; Magrini, N.; et al. Systems for grading the quality of evidence and the strength of recommendations II: Pilot study of a new system. BMC Health Serv. Res. 2005, 5, 25. [CrossRef]

108. Harbour, R.; Miller, J. A new system for grading recommendations in evidence based guidelines. BMJ 2001, 323, 334-336. [CrossRef]

109. Haidich, A.B. Meta-analysis in medical research. Hippokratia 2010, 14, 29-37.

110. Hartling, L.; Dryden, D.M.; Guthrie, A.; Muise, M.; Vandermeer, B.; Donovan, L. Benefits and harms of treating gestational diabetes mellitus: A systematic review and meta-analysis for the U.S. Preventive Services Task Force and the National Institutes of Health Office of Medical Applications of Research. Ann. Intern. Med. 2013, 159, 123-129. [CrossRef]

111. Mbuagbaw, L.; Wiysonge, C.S.; Nsagha, D.S.; Ongolo-Zogo, P.; Pantoja, T. An introduction to systematic reviews and meta-analysis: A workshop report on promoting evidence based medical practice through capacity building in research synthesis. Pan Afr. Med. J. 2011, 8, 15. [CrossRef]

112. O'Rourke, K.; Detsky, A.S. Meta-analysis in medical research: Strong encouragement for higher quality in individual research efforts. J. Clin. Epidemiol. 1989, 42, 1021-1024. [CrossRef]

113. Wende, K.; von Woedtke, T.; Weltmann, K.D.; Bekeschus, S. Chemistry and biochemistry of cold physical plasma derived reactive species in liquids. Biol. Chem. 2018, 400, 19-38. [CrossRef]

114. Medzhitov, R.; Janeway, C., Jr. Innate immunity. N. Engl. J. Med. 2000, 343, 338-344. [CrossRef] 
115. Bonilla, F.A.; Oettgen, H.C. Adaptive immunity. J. Allergy Clin. Immunol. 2010, 125, S33-S40. [CrossRef]

116. Zanoni, I.; Ostuni, R.; Marek, L.R.; Barresi, S.; Barbalat, R.; Barton, G.M.; Granucci, F.; Kagan, J.C. CD14 controls the LPS-induced endocytosis of Toll-like receptor 4. Cell 2011, 147, 868-880. [CrossRef]

117. Baran, C.P.; Zeigler, M.M.; Tridandapani, S.; Marsh, C.B. The role of ROS and RNS in regulating life and death of blood monocytes. Curr. Pharm. Des. 2004, 10, 855-866. [CrossRef]

118. Murray, P.J. Macrophage Polarization. Annu. Rev. Physiol. 2017, 79, 541-566. [CrossRef]

119. McWhorter, F.Y.; Davis, C.T.; Liu, W.F. Physical and mechanical regulation of macrophage phenotype and function. Cell. Mol. Life Sci. 2015, 72, 1303-1316. [CrossRef]

120. Castano, A.P.; Mroz, P.; Hamblin, M.R. Photodynamic therapy and anti-tumour immunity. Nat. Rev. Cancer 2006, 6, 535-545. [CrossRef]

121. Kaushik, N.K.; Kaushik, N.; Min, B.; Choi, K.H.; Hong, Y.J.; Miller, V.; Fridman, A.; Choi, E.H. Cytotoxic macrophage-released tumour necrosis factor-alpha (TNF-alpha) as a killing mechanism for cancer cell death after cold plasma activation. J. Phys. D Appl. Phys. 2016, 49, 084001. [CrossRef]

122. Freund, E.; Moritz, J.; Stope, M.; Seebauer, C.; Schmidt, A.; Bekeschus, S. Plasma-derived reactive species shape a differentiation profile in human monocytes. Appl. Sci. 2019, 9, 2530. [CrossRef]

123. Bekeschus, S.; Scherwietes, L.; Freund, E.; Liedtke, K.R.; Hackbarth, C.; von Woedtke, T.; Partecke, L.I. Plasma-treated medium tunes the inflammatory profile in murine bone marrow-derived macrophages. Clin. Plasma Med. 2018, 11,1-9. [CrossRef]

124. Bekeschus, S.; Schmidt, A.; Bethge, L.; Masur, K.; von Woedtke, T.; Hasse, S.; Wende, K. Redox stimulation of human THP-1 monocytes in response to cold physical plasma. Oxid. Med. Cell. Longev. 2016, 2016, 5910695. [CrossRef]

125. Schmidt, A.; Rodder, K.; Hasse, S.; Masur, K.; Toups, L.; Lillig, C.H.; von Woedtke, T.; Wende, K.; Bekeschus, S. Redox-regulation of activator protein 1 family members in blood cancer cell lines exposed to cold physical plasma-treated medium. Plasma Process. Polym. 2016, 13, 1179-1188. [CrossRef]

126. Kaushik, N.; Lee, S.J.; Choi, T.G.; Baik, K.Y.; Uhm, H.S.; Kim, C.H.; Kaushik, N.K.; Choi, E.H. Non-thermal plasma with 2-deoxy-D-glucose synergistically induces cell death by targeting glycolysis in blood cancer cells. Sci. Rep. 2015, 5, 8726. [CrossRef] [PubMed]

127. Bekeschus, S.; Winterbourn, C.C.; Kolata, J.; Masur, K.; Hasse, S.; Broker, B.M.; Parker, H.A. Neutrophil extracellular trap formation is elicited in response to cold physical plasma. J. Leukocyte Biol. 2016, 100, 791-799. [CrossRef] [PubMed]

128. Lin, A.; Truong, B.; Patel, S.; Kaushik, N.; Choi, E.H.; Fridman, G.; Fridman, A.; Miller, V. Nanosecond-pulsed DBD plasma-generated reactive oxygen species trigger immunogenic cell death in A549 lung carcinoma cells through intracellular oxidative stress. Int. J. Mol. Sci. 2017, 18, 966. [CrossRef]

129. Lin, A.; Truong, B.; Pappas, A.; Kirifides, L.; Oubarri, A.; Chen, S.; Lin, S.; Dobrynin, D.; Fridman, G.; Fridman, A.; et al. Uniform nanosecond pulsed dielectric barrier discharge plasma enhances anti-tumor effects by induction of immunogenic cell death in tumors and stimulation of macrophages. Plasma Process. Polym. 2015, 12, 1392-1399. [CrossRef]

130. Bundscherer, L.; Wende, K.; Ottmuller, K.; Barton, A.; Schmidt, A.; Bekeschus, S.; Hasse, S.; Weltmann, K.D.; Masur, K.; Lindequist, U. Impact of non-thermal plasma treatment on MAPK signaling pathways of human immune cell lines. Immunobiology 2013, 218, 1248-1255. [CrossRef]

131. Turrini, E.; Laurita, R.; Stancampiano, A.; Catanzaro, E.; Calcabrini, C.; Maffei, F.; Gherardi, M.; Colombo, V.; Fimognari, C. Cold atmospheric plasma induces apoptosis and oxidative stress pathway regulation in T-lymphoblastoid leukemia cells. Oxid. Med. Cell. Longev. 2017, 2017, 4271065. [CrossRef]

132. Bekeschus, S.; Schütz, C.S.; Nießner, F.; Wende, K.; Weltmann, K.-D.; Gelbrich, N.; von Woedtke, T.; Schmidt, A.; Stope, M.B. Elevated H2AX phosphorylation observed with kINPen plasma treatment is not caused by ROS-mediated DNA damage but is the consequence of apoptosis. Oxid. Med. Cell. Longev. 2019, 2019, 8535163. [CrossRef] [PubMed]

133. Crestale, L.; Laurita, R.; Liguori, A.; Stancampiano, A.; Talmon, M.; Bisag, A.; Gherardi, M.; Amoruso, A.; Colombo, V.; Fresu, L.G. Cold atmospheric pressure plasma treatment modulates human monocytes/macrophages responsiveness. Plasma 2018, 1, 261-276. [CrossRef]

134. Rodder, K.; Moritz, J.; Miller, V.; Weltmann, K.D.; Metelmann, H.R.; Gandhirajan, R.; Bekeschus, S. Activation of murine immune cells upon co-culture with plasma-treated B16F10 melanoma cells. Appl. Sci. 2019, 9, 660. [CrossRef] 
135. Hamid, O.; Robert, C.; Daud, A.; Hodi, F.S.; Hwu, W.J.; Kefford, R.; Wolchok, J.D.; Hersey, P.; Joseph, R.W.; Weber, J.S.; et al. Safety and tumor responses with lambrolizumab (anti-PD-1) in melanoma. N. Engl. J. Med. 2013, 369, 134-144. [CrossRef]

136. Hodi, F.S.; O’Day, S.J.; McDermott, D.F.; Weber, R.W.; Sosman, J.A.; Haanen, J.B.; Gonzalez, R.; Robert, C.; Schadendorf, D.; Hassel, J.C.; et al. Improved survival with ipilimumab in patients with metastatic melanoma. N. Engl. J. Med. 2010, 363, 711-723. [CrossRef]

137. Bundscherer, L.; Bekeschus, S.; Tresp, H.; Hasse, S.; Reuter, S.; Weltmann, K.-D.; Lindequist, U.; Masur, K. Viability of human blood leukocytes compared with their respective cell lines after plasma treatment. Plasma Med. 2013, 3, 71-80. [CrossRef]

138. Zuo, L.; Zhou, T.; Pannell, B.K.; Ziegler, A.C.; Best, T.M. Biological and physiological role of reactive oxygen species-The good, the bad and the ugly. Acta Physiol. 2015, 214, 329-348. [CrossRef]

139. Trachootham, D.; Alexandre, J.; Huang, P. Targeting cancer cells by ROS-mediated mechanisms: A radical therapeutic approach? Nat. Rev. Drug Discov. 2009, 8, 579-591. [CrossRef]

140. Van Loenhout, J.; Flieswasser, T.; Freire Boullosa, L.; De Waele, J.; Van Audenaerde, J.; Marcq, E.; Jacobs, J.; Lin, A.; Lion, E.; Dewitte, H.; et al. Cold atmospheric plasma-treated PBS eliminates immunosuppressive pancreatic stellate cells and induces immunogenic cell death of pancreatic cancer cells. Cancers 2019, 11, 1597. [CrossRef]

141. Azzariti, A.; Iacobazzi, R.M.; Di Fonte, R.; Porcelli, L.; Gristina, R.; Favia, P.; Fracassi, F.; Trizio, I.; Silvestris, N.; Guida, G.; et al. Plasma-activated medium triggers cell death and the presentation of immune activating danger signals in melanoma and pancreatic cancer cells. Sci. Rep. 2019, 9, 4099. [CrossRef]

142. Galluzzi, L.; Vitale, I.; Warren, S.; Adjemian, S.; Agostinis, P.; Martinez, A.B.; Chan, T.A.; Coukos, G.; Demaria, S.; Deutsch, E.; et al. Consensus guidelines for the definition, detection and interpretation of immunogenic cell death. J. Immunother. Cancer 2020, 8, e000337. [CrossRef] [PubMed]

143. Kepp, O.; Senovilla, L.; Vitale, I.; Vacchelli, E.; Adjemian, S.; Agostinis, P.; Apetoh, L.; Aranda, F.; Barnaba, V.; Bloy, N.; et al. Consensus guidelines for the detection of immunogenic cell death. Oncoimmunology 2014, 3, e955691. [CrossRef] [PubMed]

144. Liedtke, K.R.; Freund, E.; Hackbarth, C.; Heidecke, C.D.; Partecke, L.I.; Bekeschus, S. A myeloid and lymphoid infiltrate in murine pancreatic tumors exposed to plasma-treated medium. Clin. Plasma Med. 2018, 11, 10-17. [CrossRef]

145. Liedtke, K.R.; Bekeschus, S.; Kaeding, A.; Hackbarth, C.; Kuehn, J.P.; Heidecke, C.D.; von Bernstorff, W.; von Woedtke, T.; Partecke, L.I. Non-thermal plasma-treated solution demonstrates antitumor activity against pancreatic cancer cells in vitro and in vivo. Sci. Rep. 2017, 7, 8319. [CrossRef] [PubMed]

146. Mizuno, K.; Yonetamari, K.; Shirakawa, Y.; Akiyama, T.; Ono, R. Anti-tumor immune response induced by nanosecond pulsed streamer discharge in mice. J. Phys. D Appl. Phys. 2017, 50, 12LT01. [CrossRef]

147. Lee, Y.S.; Lee, M.H.; Kim, H.J.; Won, H.R.; Kim, C.H. Non-thermal atmospheric plasma ameliorates imiquimod-induced psoriasis-like skin inflammation in mice through inhibition of immune responses and up-regulation of PD-L1 expression. Sci. Rep. 2017, 7, 15564. [CrossRef]

148. Lee, M.H.; Lee, Y.S.; Kim, H.J.; Han, C.H.; Kang, S.U.; Kim, C.H. Non-thermal plasma inhibits mast cell activation and ameliorates allergic skin inflammatory diseases in NC/Nga mice. Sci. Rep. 2019, 9, 13510. [CrossRef]

149. Ioannidis, J.P.A. Why most published research findings are false. PLoS Med. 2005, 2, 696-701. [CrossRef]

150. Ioannidis, J.P.A. Why most published research findings are false: Author's reply to Goodman and Greenland. PLoS Med. 2007, 4, 1132-1133. [CrossRef]

151. Baker, M. 1500 scientists lift the lid on reproducibility. Nature 2016, 533, 452-454. [CrossRef]

152. Fang, F.C.; Steen, R.G.; Casadevall, A. Misconduct accounts for the majority of retracted scientific publications. Proc. Natl. Acad. Sci. USA 2012, 109, 17028-17033. [CrossRef] [PubMed]

153. Harris, R. Rigor Mortis: How Sloppy Science Creates Worthless Cures, Crushes Hope, and Wastes Billions, 1st ed.; Basic Books: New York, NY, USA, 2017; p. 288.

154. Begley, C.G.; Ellis, L.M. Drug development: Raise standards for preclinical cancer research. Nature 2012, 483, 531-533. [CrossRef]

155. Freedman, L.P.; Cockburn, I.M.; Simcoe, T.S. The economics of reproducibility in preclinical research. PLoS Biol. 2015, 13, e1002165. [CrossRef] [PubMed] 
156. Hines, W.C.; Su, Y.; Kuhn, I.; Polyak, K.; Bissell, M.J. Sorting out the FACS: A devil in the details. Cell Rep. 2014, 6, 779-781. [CrossRef]

157. Abrink, M.; Gobl, A.E.; Huang, R.; Nilsson, K.; Hellman, L. Human cell lines U-937, THP-1 and Mono Mac 6 represent relatively immature cells of the monocyte-macrophage cell lineage. Leukemia 1994, 8, 1579-1584. [PubMed]

158. Xia, T.; Kovochich, M.; Brant, J.; Hotze, M.; Sempf, J.; Oberley, T.; Sioutas, C.; Yeh, J.I.; Wiesner, M.R.; Nel, A.E. Comparison of the abilities of ambient and manufactured nanoparticles to induce cellular toxicity according to an oxidative stress paradigm. Nano Lett. 2006, 6, 1794-1807. [CrossRef]

159. Xia, T.; Kovochich, M.; Liong, M.; Zink, J.I.; Nel, A.E. Cationic polystyrene nanosphere toxicity depends on cell-specific endocytic and mitochondrial injury pathways. ACS Nano 2008, 2, 85-96. [CrossRef] [PubMed]

160. Schwende, H.; Fitzke, E.; Ambs, P.; Dieter, P. Differences in the state of differentiation of THP-1 cells induced by phorbol ester and 1,25-dihydroxyvitamin D3. J. Leukoc. Biol. 1996, 59, 555-561. [CrossRef]

161. Daigneault, M.; Preston, J.A.; Marriott, H.M.; Whyte, M.K.; Dockrell, D.H. The identification of markers of macrophage differentiation in PMA-stimulated THP-1 cells and monocyte-derived macrophages. PLoS ONE 2010, 5, e8668. [CrossRef]

162. Kohro, T.; Tanaka, T.; Murakami, T.; Wada, Y.; Aburatani, H.; Hamakubo, T.; Kodama, T. A comparison of differences in the gene expression profiles of phorbol 12-myristate 13-acetate differentiated THP-1 cells and human monocyte-derived macrophage. J. Atheroscler. Thromb. 2004, 11, 88-97. [CrossRef]

163. Prinz, F.; Schlange, T.; Asadullah, K. Believe it or not: How much can we rely on published data on potential drug targets? Nat. Rev. Drug Discov. 2011, 10, 712. [CrossRef] [PubMed]

164. Swinney, D.C. Biochemical mechanisms of drug action: What does it take for success? Nat. Rev. Drug Discov. 2004, 3, 801-808. [CrossRef] [PubMed]

165. Chernajovsky, Y. The importance of understanding the molecular mechanisms of resistance to biologics. Rheumatology 2012, 51, 397-398. [CrossRef]

166. Scannell, J.W.; Blanckley, A.; Boldon, H.; Warrington, B. Diagnosing the decline in pharmaceutical R\&D efficiency. Nat. Rev. Drug Discov. 2012, 11, 191-200. [PubMed]

167. Bae, Y.H.; Park, K. Targeted drug delivery to tumors: Myths, reality and possibility. J. Control. Release 2011, 153, 198-205. [CrossRef] [PubMed] 